\title{
Yeterince akım ölçümü olmayan nehirlerde taşkın debisinin hesaplanması ve taşkın modellemesi (Samsun, Mert Irmağı örneği)
}

\author{
Vahdettin Demir*1 ${ }^{\circledR}$, Aslı Ülke Keskin² \\ ${ }^{1}$ KTO Karatay Üniversitesi, Mühendislik ve Doğa Bilimleri Fakültesi, İșaat Mühendisliği Bölümü, Konya, Türkiye \\ 2 Ondokuzmayıs Üniversitesi, Mühendislik Fakültesi, İșaat Mühendisliği Bölümü, Samsun, Türkiye
}

\author{
Anahtar Kelimeler \\ Tașkın tekerrür debisi \\ Frekans analizi \\ Tașkın modellemesi \\ CBS
}

\begin{abstract}
ÖZ
Taşkınlar dünyada yaşanan en önemli afetlerden biri olup, Türkiye'de can ve mal kayıpları açısından depremlerden sonra ikinci, meteorolojik afetler arasında ilk sırada yer alır. Yaşamımızı, ekonomimizi etkileyen bu afetin yapısının araștırılması ve kayıpları en aza indirmek için önlemlerin alınması büyük önem arz etmektedir. Bu çalışmanın amacı yeterince akım ölçümü olmayan Samsun, Mert Irmağı için birim hidrograf yöntemlerini kullanarak taşkın tekerrür debilerinin elde edilmesi ve belli tekerrürlerdeki taşkın hidrograflarının çalıșma alanında olușturduğu tașkın yayılımının modellenmesidir. Tașkın tekerrür hidrograflarının belirlenmesinde yağış-akış modellemesine dayalı Mockus, Synder ve DSí Sentetik yöntemleri kullanılmıştır. Yöntemler uygulanırken Mert Irmağı havzasını temsilen, havzayı kapsayan 3 adet meteoroloji istasyonunun (Samsun, Çakıralan, Mazlumoğlu) yağıș verileri kullanılmıștır. Belli tekerrürlerdeki maksimum yağıș verilerine en iyi uyum gösteren dağılım istatistiksel dağılımlar kullanılarak belirlenmiştir. Kullanılan istatistiksel dağılımlar Normal dağılım, Log-Normal dağılım, Gumbel, Log-Pearson, Pearson dağılımlarıdır. En uygun dağılım ise Kolmogorov-Smirnov uygunluk testi ile belirlenmiștir. Ardından elde edilen maksimum yağış yükseklikleri kullanılarak akım değerleri ve taşkın hidrografları elde edilmiştir. Böylece çalışmanın taşkın modelleme aşamasında geçilmiş ve elde edilen taşkın debileri ve hidrografı FLO-2D programı kullanılarak modellenmiștir. Tașkın yayılım alanları ve su yükseklikleri farklı tekerrürlerde incelenerek, ırmak üzerinde yer alan köprüler ve yapılaşmanın olduğu bölgeler için önerilerde bulunulmuştur.
\end{abstract}

\section{Flood flow calculation and flood modeling in rivers that do not have enough flow measurement (Samsun, Mert River sample)}

\section{Keywords}

Flood return periods

Frequency analysis

Flood modelling

GIS

\begin{abstract}
Floods are among the most important disasters in the world. After the earthquakes in terms of loss of life and property in Turkey in second place, it takes the first place among meteorological disasters. It is very important to investigate the structure of this disaster affecting our lives and economy and to take measures to minimize losses. The aim of this study is to obtain flood return period flow rates by using unit hydrograph methods for Samsun, Mert river which does not have enough flow measurement and to model flood propagation of flood hydrographs in return periods. The Mockus, Synder and DSI Synthetic methods based on precipitation-flow modeling were used in the determination of flood return period hydrographs. The precipitation data of the stations covering the Mert River basin were used in the application of the methods. The distribution that best matches the maximum precipitation data in return periods was determined using statistical distributions. The statistical distributions used are Normal distribution, Log-Normal distribution, Gumbel, LogPearson, Pearson distributions. The most appropriate distribution was determined by the Kolmogorov-Smirnov conformity test. Then, maximum precipitation heights were obtained, and current values and hydrographs were obtained. Thus, the flood modeling phase of the study was passed, and the flood flow rates obtained were modeled by using the FLO-2D program. Flood propagation areas and water heights were examined in different return period and suggestions were made for the bridges and urban areas near the river.
\end{abstract}

\footnotetext{
${ }^{*}$ Sorumlu Yazar

*(vahdettin.demir@karatay.edu.tr) ORCID ID 0000-0002-6590-5658

(asli.ulke@omu.edu.tr) ORCID ID 0000-0002-9676-8377
} 


\section{GíRIş}

Taşkın, nehir yatağında bulunan su miktarının; normalden fazla yağış yağması, mevcut kar örtüsünün erimesi, heyelan, barajdan kontrolsüz su bırakılması, nehir yatağının kesitinin değiştirilmesi gibi nedenlerle akarsu yatak kesitine sığamayarak, çevresindeki arazilere, yerleşim yerlerine, alt yapı tesislerine ve canlılara zarar vererek bölgede ekonomik ve sosyal faaliyetleri kesintiye uğratan doğal bir afettir. Dünyada ve ülkemizde can ve mal kayıpları açısından tüm afetler arasında ikinci, meteorolojik afetler arasında ise ilk sırada yer almaktadır. Mevcut veriler incelendiğinde taşkınlardan kaynaklanan ekonomik kayıp her yl yaklaşık olarak 300 milyon €'dir. Ülkemizde 1975-2015 yılları arasında meydana gelen taşkın olayları ve etkileri incelediğinde; toplamda 1209 defa taşkın meydana gelmiş, 720 kişi hayatını kaybetmiş ve 893993 ha alan su altında kalmıştır. En fazla taşkının meydana geldiği yıl 2015 yılı (122 kez) olup en fazla can kaybının yaşandığ yıl da 164 kiși ile 1995 yılıdır. 1975-2002 yılları arasında yaşanan toplam taşkın sayısı 487 olup, toplam can kaybı 493'tür. 2003-2015 döneminde değerlendirilen toplam taşkın sayısı 722, toplam can kaybı 227'dir (DSİ, 2017).

Yaşamımızı etkileyen taşkınların maddi ve manevi zararlarını azaltmak için taşkını afet haline getiren mekanizmasının iyi bilinmesi ve taşkın meydana gelmeden önce önlemlerin alınması gerekmektedir. Akarsu yatağına yapılan müdahaleler, plansız şehirleşme, arazi kullanım şeklinin değişmesi ve iklim değişikliği gibi nedenlerle meydana gelen taşkınların önceden tahmin edilmesi, gözlem değeri yardımıyla istatistiksel analizlerin ve modelleme çalışmalarının yapılmasıyla mümkün olmaktadır. Taşkın debilerinin bulunması özellikle su yapılarının proje tasarımında ihtiyaç duyulan temel verilerdendir. Mühendisin veya araştırmacının alacakları kararların temelinde, sayısal gözlemler veya ölçümler yer alır. Bu ham bilgiler, yani işlenmemiş veriler, ancak uygun bir istatistik analize tabi tutulduğunda, anlamlı ve anlaşılır sonuçların çıkarılmasına imkân verir. Örneğin barajlar, köprüler, kanalizasyon ve içme suyu şebekeleri gibi su yapılarının boyutlandırılması bu kapsamın içinde yer alır. $\mathrm{Bu}$ ve benzeri konularda nümerik verilen toplanması çalışmanın ilk adımını oluştururken, ikinci adım, toplanmış olan bu verilerin sınıflandırılması, yani meydana gelme zamanı, büyüklüğü ve yeri gibi farklılıklara göre sıraya konulmasıdır. Son işlem ise sınıflandırılmış bilgilerin genelleştirilmesidir.

Taşkın ve taşkın alanları üzerine yapılacak detaylı bir çalıșma; hidrolojik, hidrolik, topografik ve diğer ilișkili unsurların zamansal ve alansal boyutta analizini yapmayı gerektirir. Son yıllarda, sayısal modellerle taşkın yatağı belirleme tekniği taşkınların nerede, hangi yükseklikte, ne kadar süre sonra oluşacağının daha doğru tahmini için kullanılmaya başlanmıștır. Bu yöntem sayesinde, taşkın tahminlerinin daha doğru, daha kısa sürede yapılması sağlanmaktadır (Onuşluel Gül \& Gül, 2010). Meteorolojik karakterli doğal afetlerden olan taşkınların sayısı, sıklığı ve zararları, küresel ısınma ve iklim değişikliğinin de etkisi ile artmaktadır (Akgül, 2018). Taşkın afetlerini yalnızca meteorolojik oluşumlara bağlı olarak ifade etmek mümkün değildir.
Özellikle Türkiye gibi ekonomik gelişme faaliyetinin yoğun bir biçimde devam ettiği ülkelerde, sanayileşme ve sektör çeşitliliğinin beraberinde getirdiği kentleșme faaliyetleri, havza bütünündeki hidrolojik dengeyi bozmakta ve sonucunda büyük miktarda can ve mal kaybına yol açan taşkınlar meydana gelmektedir (Beden ve ark., 2014; Yılmaz, 2016). Havzalarda meydana gelebilecek taşkınları tahmin etmek oldukça güç bir konu olsa da meteorolojik ve hidrolojik gözlem istasyonlarında ölçülmüş verilerle (yağış, sıcaklık, akım miktarı, maksimum ve minimum su yükseklikleri gibi) çeşitli metotlar kullanılarak taşkın alanları ve taşkın debileri tahmin edilebilir. Bu tahminlere göre mevcut durumun gözden geçirilmesi ve gerekli tedbirlerin alınması can ve mal kaybının en aza indirilmesi mümkün olabilmektedir (Ülke ve ark., 2013). Nehir üzerinde akım istasyonunun bulunması durumunda istatistiksel dağılımlara göre tașkın debileri belirlenebilir. Fakat birçok istatistiksel analizde olduğu gibi en az 30 yıllık ölçülmüş akım verisinin kayıt altına alınmış olması gereklidir. Nehir üzerinde akım istasyonunun bulunmaması durumunda ise gelmesi muhtemel taşkın debileri, meteoroloji gözlem istasyonlarından elde edilen yağış verileri ve istasyon bilgilerine göre (konum, plüviyograf oranları vb.) hesaplanır (Anlı, 2006).

Akış, yağış gibi parametrelerin extrem değerleri frekans analizine göre belirlenir. Frekans analizi ilgili parametrenin hangi aralıklarla meydana geleceğinin belirlenmesi olarak tanımlanabilir (Benson, 1968). Taşkın frekans analizi ise su yapılarının veya suyla ilgili projelerin ekonomik olarak değerlendirilmesinde önemlidir. Frekans analizi, extrem olayların gelecekteki büyüklüğünün ve meydana gelme süresinin (tekerrür süresinin) tahmini ile hidrolik yapıların optimum tasarımının sağlanması ve proje maliyetinin düșürülmesi açısından önemlidir. $\mathrm{Bu}$ nedenle bir havzada meydana gelen akımlara istatistiksel frekans analiz yöntemleri uygulanarak bu akımlara uygun olasılık dağılımları saptanabilir (Singh, 1980). Fakat tüm nehirlerde istatistiksel analizler için yeterince gözleme sahip veri bulunmayabilmektedir. Böyle durumlarda havza yönetimi ve taşkın modellerinin oluşturulması olası kayıpları önlemek için büyük öneme sahiptir. Taşkın modellemesinde taşkın alanlarının belirlenmesi, haritalandırılması ve elde edilen çıtılar ile havza planlaması yapılmaktadır. Taşkın modellemesinde ihtiyaç duyulan temel girdi ise taşkın tekerrür debileridir. Debilerin muhtemel taşkın değerlerinden daha küçük hesaplanması taşkın modellerinin gerçeği yansitmamasina ve maddi manevi kayı risklerinin artmasına sebep olurken, debilerin muhtemel taşkın değerlerinden daha büyük hesaplanması ise gereken önlemin boyutunu ve bu da maliyeti artıracaktır (Kumanlığlu \& Ersoy, 2018).

Akarsu havzasına ait akım verilerinin yeterli olması durumunda, taşkın debilerinin hesabında istatistik yöntemler olumlu sonuçlar vermektedir (Sönmez ve ark.., 2012). Taşkın tekerrür debilerinin istatistiksel yöntemlerle belirlenmesiyle ilgili literatürde yer alan çalışmalar incelendiğinde; Seçkin (2002), Seyhan ve Ceyhan Havzaları için bölgesel taşkın frekans analizi boyutsuz olarak incelenmiş, havzalar homojen alt bölgelere ayrıldıktan sonra Log Lojistik, Log Pearson tip 
3, Pearson tip 3, Wakeby, Log Boughton, Gumbel ve Log Normal dağılımları kullanılarak spreadsheet programı yardımıyla bölgesel tașkın frekans eğrileri elde edilmiștir. Kaleyci (2004), Karadeniz Bölgesi'nde yer alan Değirmendere'nin çeşitli yinelemeli taşkın debileri ile bunların sebep olduğu su yüzeyi kotları ve taşkın sahalarını araștırıp, tașkın tahmin hesaplarında sonuçları karşılaştırmak amacıyla hem istatistiki yöntemler hem de birim hidrograf yöntemleri kullanmıştır. Şahin (2007), taşkın frekans analizindeki bağımsızlık tezinin geçerliliğini incelemek amacıyla beş bağımlılık testini Gevaş-Gürpınar Havzası'nda bulunan 12 adet akım gözlem istasyonuna ait yıllık pik akım serilerine uygulamıştır. Hakan (2008), çalışmasında Türkiye'nin en büyük debiye sahip akarsularından biri olan Kızılırmak Nehri üzerinde bulunan üç akım gözlem istasyonuna (Yamula, Gülșehir, Söğütlühan) ait akım verilerini istatistiksel olarak analiz ederek, parametrik ve non-parametrik yaklaşımları karşılaștırmış olup frekans histogramlarına uygunluğunu incelemiştir. Seçkin (2009), dağılım parametrelerini tahmin etmek için L-momentler tekniğini kullanarak Türkiye'de bulunan 26 havzadaki 455 istasyona ait su yll maksimum akım değerlerine bölgesel taşkın frekans analizi uygulamıştır. Şahin (2013), Bölgesel Taşkın Frekans Analizi (BTFA) yöntemlerini Ceyhan havzasına uygulamış, çalışmada doğrusal olmayan regresyon analiz yöntemleri de çok değişkenli istatistiksel yöntemler olarak havzadaki taşkını hesaplamak adına havza parametreleri ile birlikte kullanmıştır. Şeker (2015), taşkın frekans analizi için Antalya Havzasında yer alan 28 istasyona ait 1961-2000 yılları arasındaki yıllık anlık maksimum akım verilerini kullanmıştır. Bu istasyonların hangi dağılıma uygun olduğu öncelikle tespit edilmiş ardından her istasyon için olasılık yoğunluk fonksiyonu ve kümülatif dağılım fonksiyonu elde edilip ve $2,5,10$, $20,30,40,50,75,100,500$ ve 1000 yıllık taşkın tekerrür debileri bulunmuştur. Akış verilerinin yetersiz olması veya verilerin olmaması durumu için sentetik birim hidrograflar yöntemi geliştirilmiştir (Sönmez ve ark., 2012). Taşkın akımlarının belirlenmesinde üzerinde akım gözlemi olmayan havzalarda Mockus, SCS, Snyder, DSİ Sentetik gibi yöntemler literatürde sıklıkla kullanılmaktadır. Literatürde yer alan çalışmalar incelendiğinde Sönmez ve ark (2012) İstanbul deresinin taşkın debilerinin tahmininde, Aydın ve Bağatur (2016), Göksu nehri havzasında, Keskiner ve Çetin (2016), Yaylalık göletinde, Sönmez ve ark. (2017), Mudurnu çayında, Dikici ve Alhan (2018), Alibeyköy havzasında, Keskin ve ark. (2018), Karabük Eskipazar çayında tașkın debilerinin hesaplanmasında sözü geçen yöntemlerin kullanıldığı görülmektedir. İşler ve ark. (2016), Antalya Kemer İlçesi için gerçekleştirdikleri taşkın çalışmasında DSİ istasyonları için aynı sentetik yöntemler kullanılmış ve önerilmiştir. Yöntemlerin uygunluğu ise akım istasyonunun bulunduğu drenaj havzasının boyutlarına ve karakteristik özelliklerine göre bölgeden bölgeye değişmektedir.

$\mathrm{Bu}$ çalışmada üzerinde akım istasyonu bulunan fakat istatistiksel analizler için yeterince ölçümü olmayan Mert Irmağı için taşkın tekerrür debileri hesaplanmıştır. Çalışmada Mert Irmağı havzasını temsil eden Samsun bölge, Çakıralan ve Mazlumoğlu meteoroloji gözlem istasyonları kullanılmıştır. Gözlem istasyonlarında kayıtlı yağıș verilerine ait uygun istatistiksel dağılımlar (Normal dağılım, Log Normal dağılım, Gumbel, LogPearson, Pearson) belirlenmiștir. Verilere en uygun istatistiksel dağılımların belirlenmesinde ise Kolmogrov Smirnov testi kullanılmıştır. Böylece 2, 5, 10, 25, 50, 100 ve 500 yıllık tekerrürlere sahip yağıș değerleri elde edilmiştir. Bu yağış değerleri ile Mockus, Snyder, DSİ Sentetik gibi birim hidrograf yöntemleri kullanılarak da havzaya uygun taşkın tekerrür debileri elde edilmiştir. Kullanılan yöntemler arasında karar verilirken havza karakteristik özellikleri ve çalışma alanına yakın benzer özelliklerdeki akım istasyonlarının bölgesel ve noktasal taşkın debileri dikkate alınmıştır. Bu aşamadan sonra taşkın modelleme aşamasına geçilmiş, 1/1000 ölçekli halihazır haritalar ve imar planları kullanılarak yüzey modeli, nehir üzerinden alınan örnekler ve uzaktan algılama-sınıflandırma teknikleriyle de Manning pürüzlülük katsayıları elde edilmiștir. Tüm bu veriler iki boyutlu taşkın model paket programı FLO-2D ile modellenmiştir. Böylece belli taşkın tekerrür sürelerindeki ( $Q_{50}, Q_{100}, Q_{500}$ ve $\left.Q_{1000}\right)$ taşkın senaryoları oluşturulmuş, su yayılım alanları belirlenmiş. Elde edilen taşkın yayılım haritaları neticesinde taşkın anında Mert Irmağı'nın sağ ve sol sahilinde meydana gelecek su derinlikleri tespit edilmiș ve rrmak üzerinde bulunan köprülerin tekerrür debilerinde riskli olup olmadıkları incelenmiştir. Bu çalışmayla taşkın modellemesi, taşkın debilerinin hesaplanması, bu debilerin modellenmesine ve önerilere kadar bir bütün olarak ele alınmış, yerel bir soruna çözüm önerisi getirilmiștir.

\section{METOD}

\subsection{Tașkın Tekerrür Debilerinin Belirlenmesi}

Taşkın debileri hesaplanacak havzanın büyüklüğü, karakteristik özellikleri, yağış ve akış verilerinin mevcudiyeti ve sonrasında yaplacak hidrolik modellemenin ihtiyacına göre çeşitli yöntemlerle elde edilmektedir. Taşkın debilerinin hesaplanmasında 2 temel yöntem önerilmektedir; Taşkın frekans analizi (istatistiksel), Yağış-akış modeli (sentetik) (DSİ, 2017).

Taşkın frekans analizinde taşkın debileri yıllık anlık maksimum akım verileri, Olasılık Dağılım Fonksiyonları (ODF), Noktasal ve Bölgesel Taşkın Frekans Analiz yöntemleriyle elde edilmektedir. Çalışmada literatürde en çok tercih edilen 5 farklı OYF'nu (Olasılık Yoğunluk Fonksiyonu) kullanılmıştır. Bunlar; Normal dağılım, LogNormal Tip-2, Log-Normal Tip-3, Gumbel, Log-Pearson Tip-3, Pearson dağılımlarıdır. Yağış-akış modeli ise taşkın debileri, hesaplanacak nehirde yeteri kadar gözlem verisi bulunmayan veya havzasında hiç istasyon bulunmayan bölgelerde kullanılmaktadır. Çalışma alanında yağış istasyonları yardımıyla oluşturulacak Thiessen poligonları ve çevre istasyon verileri yardımıyla taşkın debileri birim hidrograf sentetik yöntemlerle elde edilmiştir. Çalışmada kapsamında literatürde en çok kullanılan Mockus, DSİ sentetik, Synder yöntemleri kullanılmıştır (Demir, 2020). 


\subsubsection{Olasılık dağılım fonksiyonları}

\subsubsection{Normal dağılım}

Normal dağılıma göre bir rastgele değişken (X), n adet bağımsız değişkenin toplamından meydana geliyorsa $n$ arttıkça X'in dağılımı esas değişkenlerin dağılımı ne olursa olsun hızla normal dağılıma yaklaşır. X normal rastgele değişkenin olasılık yoğunluk fonksiyonu (OYF) Eş. 1'de verilmiştir (Bayazıt \& Yeğen Oğuz, 2013).

$$
f(x)=\frac{1}{\sqrt{2 \pi \sigma_{x}^{2}}} \exp \left[-\frac{1}{2}\left(\frac{\left(x-\mu_{x}\right.}{\sigma_{x}}\right)^{2}\right]
$$

Dağılım $(-\infty \leq x \leq \infty)$ arasında olup ortalaması $\mu_{\mathrm{x}}$, varyansı $\sigma_{\mathrm{x}}{ }^{2}$ dır. Normal dağılım simetrik olup çarpıklık katsayısı sıfır ve kurtosis 3'dür (Bayazıt \& Yeğen Oğuz, 2013).

\subsubsection{Log-Normal dağılım}

$\mathrm{X}$ değișkeninin logaritması ile tanımlanan Y değișkeni normal dağılmış ise X'in dağılımı log-normaldir (Eş. 2). Dağılım X>0 için tanımlanabileceğinden hidrolojideki birçok pozitif çarpık değişkene iyi uymaktadır.

$$
\begin{aligned}
& Y=\ln (x) \\
& X=\exp (Y)
\end{aligned}
$$

X log-normal değişkeninin Eklenik Dağılım Fonksiyonu (EDF) Eș.4'de verilmiștir.

$$
F(x)=P[Y \leq \ln (x)]=P\left[\frac{Y-\mu_{y}}{\sigma_{y}} \leq \frac{\ln (x)-\mu_{y}}{\sigma_{y}}\right]=\varphi\left[\frac{\ln (x)-\mu_{y}}{\sigma_{y}}\right]
$$

$\mathrm{Bu}$ ifadede $\varphi$ standart normal dağılımın eklenik dağılım fonksiyonudur (Bayazıt \& Yeğen Oğuz, 2013).

\subsubsection{3. Üç-parametreli Log-Normal dağılım}

$\mathrm{X}$ rastgele değişkenin logaritması bazı durumlarda normal dağılıma pek uymamaktadır. Fakat $\mathrm{X}_{0}$ gibi bir alt sınır değeri çıkarıldıktan sonra logaritmik dönüşüm yapıldığında değișken normal dağılıma uyabilmektedir (Eş 5.).

$$
Y=\ln (x)
$$

$\mathrm{X}_{0}$ alt sınır olup Y'nin dağılımı normal dağılım (Eş. 6) olmaktadır (Bayazıt \& Yeğen Oğuz, 2013).

$$
X=X_{0}+\exp (Y)
$$

\subsubsection{Gumbel dağılımı}

$\mathrm{Bu}$ yöntemde, bağımsız değişkenlerin sayısının sonsuza gitmesi halinde örneklerdeki en büyüklerin dağılımının ekstrem değer dağılımlarından birine yakınsadığı kabul edilir (Bayazıt, Önöz, 2008; Bayazıt \& Yeğen Oğuz, 2013). Gumbel dağılımının OYF ve EDF Eş. 7 ve 8 'de yer almaktadır;

$$
f(x)=\frac{1}{a} \exp \left[-\frac{x-\xi}{a}-\exp \left(-\frac{x-\xi}{a}\right)\right]
$$

$$
F(x)=\exp \left[-\exp \left(-\frac{x-\xi}{a}\right)\right]
$$

Gumbel dağılımının OYF, Log-Normal dağılımının Csx=1,13 olan dağılımına çok benzerdir. Dağılım parametreleri ( $\xi$ ve $\alpha$ ) değişince Gumbel OYF'nin merkezi hareket etmekle birlikte çarpıklık katsayısı sabit olduğundan biçimi değişmez (Bayazıt \& Yeğen Oğuz, 2013).

\subsubsection{Log-pearson tip III (LP3)}

Bir rastgele değişkenin logaritmaları $\mathrm{P}_{3}$ dağılmıș ise (Y değişkeni) esas değişkenin (X) dağılımı LP3 olur (Eş 9, 10).

$$
\begin{aligned}
& Y=\ln (x) \\
& X=\exp (Y)
\end{aligned}
$$

$\alpha$ biçim, $\beta$ ölçek ve $\xi$ yer parametresi olmak üzere dağılımın OYF Eş. 11'de yer almaktadır (Bayazıt \& Yeğen Oğuz, 2013).

$$
f(x)=|\beta|[\beta(x-\xi)]^{a-1} \frac{\exp \{(-\beta[\ln (x)-\xi])\}}{a \Gamma(a)}
$$

Olasılık yoğunluk fonksiyonları hakkında ayrıntılı bilgi için atıf verilen çalışmalar incelenebilir (Bayazıt \& Önöz, 2008; Haktanir ve ark., 2016; Maidment, 1992).

\subsubsection{Kolmogorov-Smirnov (KS) Testi}

Tek örnek için KS testi iki kümülatif dağılım fonksiyonunun incelenmesi temeline dayanır (Gamgam, 1998). Bunlardan birincisi sıfir hipotezinde belirtilen kümülatif dağılım fonksiyonudur. İkincisi örnekten elde edilen gözlenen kümülatif dağılım fonksiyonudur. KS tek örnek testinde hipotezler (o: observed, e: expected):

- $\mathrm{H}_{\mathrm{o}}: \mathrm{O}_{\mathrm{i}}=\mathrm{e}_{\mathrm{i}}$ (Gözlenen frekanslar beklenen frekanslara uygundur),

- $\mathrm{H}_{\mathrm{a}}: \mathrm{O}_{\mathrm{i}} \neq \mathrm{e}_{\mathrm{i}}$ (Gözlenen frekanslar beklenen frekanslara uygun değildir. Aralarındaki fark önemlidir)

Test istatistiği $\Delta$ ile gösterilir (Eş. 12). $\Delta$; gözlenen ve beklenen değerlerin kümülatif nispi frekansları arasındaki mutlak farkın en büyügüüür (Bircan ve ark., 2003; Kartal, 1998; Kolmogorov, 1933; Smirnov, 1939).

$$
\Delta=\max \left|F_{o}-F_{e}\right|
$$

$\mathrm{F}_{\mathrm{o}}$; gözlenen kümülatif nispi frekans, $\mathrm{F}_{\mathrm{e}}$; beklenen kümülatif nispi frekanstır. $\Delta$ istatistiği için örnek dağılımından elde edilen kritik değerler KolmogorovSmirnov uyum iyiliği testine ilişkin tablodan n ve $1-\alpha(\alpha$; anlamlılık düzeyi olmak üzere) değerlerine göre bulunan $\Delta_{\mathrm{k}}$ değeri ve örnekten hesaplanan değer $\Delta_{\mathrm{h}}$ olmak üzere, $\Delta_{\mathrm{h}}<\Delta_{\mathrm{k}}$ ise $\mathrm{H}_{\mathrm{o}}$ kabul edilir, (yani $\mathrm{H}_{\mathrm{a}}$ red edilirse) gözlenen frekansların beklenen frekanslara uygun olduğu söylenir (Yıldırım, 2013). 


\subsubsection{Sentetik birim hidrograf yöntemleri}

\subsubsection{Synder yöntemi}

Snyder yönteminin temel formülleri ve formülde yer alan parametreler; Akarsu havzasının ağırlık merkeziyle taşkın hidrografının tepe noktası arasındaki $\left(\mathrm{t}_{\mathrm{p}}\right)$ zaman farkı saat olarak Eş. 13'te verilmiștir (Çavdar, 1996). C $\mathrm{t}_{\mathrm{t}}$ ve $\mathrm{C}_{\mathrm{p}}$; zemine bağlı katsayılar ise Tablo 1'de yer almaktadır.

$$
t_{p}=C_{t} *\left(L^{*} L_{c}\right)^{0.3}
$$

Tablo 1. Zemine bağlı Ct ve Cp katsayıları

\begin{tabular}{lll}
\hline Zemin Cinsi & $\mathrm{Ct}$ & $\mathrm{Cp}$ \\
\hline Kumlu & 1.65 & 0.56 \\
Balçık & 1.50 & 0.63 \\
Killi veya kayalık & 1.35 & 0.69 \\
\hline
\end{tabular}

Eş 13'te $\mathrm{L}_{c}$ : havza alanı ağırlık merkezinin havza giriş veya çıkış noktasına olan en uzun mesafesidir $(\mathrm{km})$. L ise Havza uzunluğudur (km). Şekil 1'de Mert Irmağı havzası üzerinde $L$ ve $L_{c}$ uzunlukları verilmiștir.

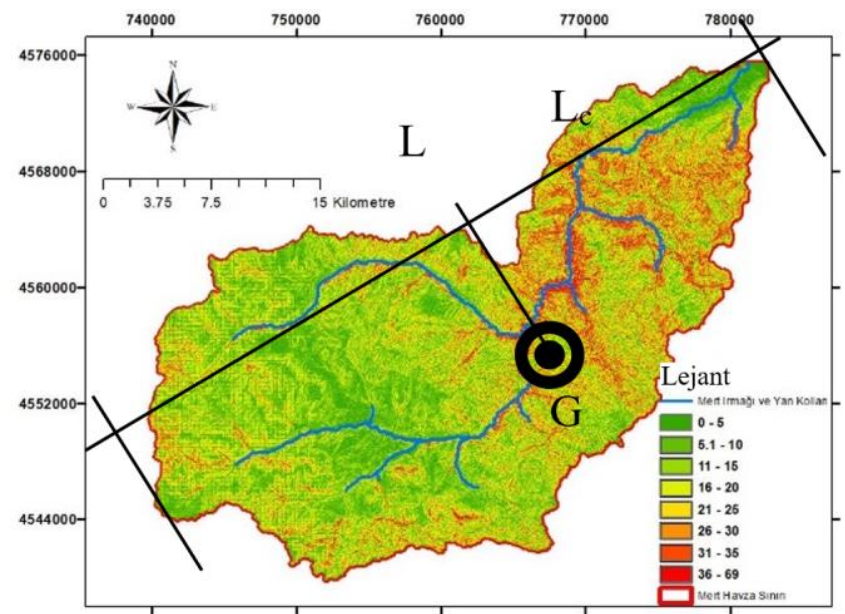

Şekil 1. Snyder yöntemi şeması (Vahdettin Demir, 2020)

Birim hidrografa ait sağanak süresi $\left(\mathrm{t}_{\mathrm{r}}\right)$, Eş. 14 ile hesap edilmektedir.

$$
t_{r}=\frac{t_{p}}{5.5}
$$

Burada; tr: Birim hidrografa ait sağanak süresi (saat). Taşkın hidrografının tepe noktasındaki birim taşkın debisi $\left(q_{p}\right)$ değeri Eş. 15 ile elde edilmektedir.

$$
q_{p}=\frac{2760 * C_{p}}{t_{p}}\left(1 / \mathrm{s} / \mathrm{km}^{2} / \mathrm{cm}\right)
$$

Buradan tașkın tepe noktasındaki debi $\left(\mathrm{Q}_{\mathrm{P}}\right)$ değeri Eș. 16 ile hesaplanmaktadır.

$$
Q_{p}=q_{p} * A * 10^{-3}\left(\mathrm{~m}^{3} / \mathrm{s} / \mathrm{cm}\right)
$$

Burada; A: havza alanı $\left(\mathrm{km}^{2}\right)$. Snyder yöntemi yağış alanı $1000 \mathrm{~km}^{2}$ 'ye eşit veya daha büyük havzalar (üst sınır $5000 \mathrm{~km}^{2}$ ) için önerilmektedir (DSİ, 2012; Özdemir, 1978).

\subsubsection{Mockus yöntemi}

Mockus yöntemi, toplanma zamanı ( $\mathrm{t}_{\mathrm{c}}$ ) 30 saate kadar olan ve $1000 \mathrm{~km}^{2}$ 'den küçük drenaj alanları ve için uygulanabilmektedir (DSİ, 2012; Özdemir, 1978). Daha büyük alanlarda drenaj alanı tali parçalara ayrılarak her bir parça için çizilecek hidrograflar geciktirme sürelerine göre süperpoze edilmektedir. Yağışın değişkenliği nedeniyle hesaplanacak taşkınlarda alınacak $\Delta \mathrm{D}$ birim sağanak süresinin doğru seçilmesi önemlidir. $\Delta \mathrm{D}$ birim sağanak süresinin seçiminde genel kriter Eş. 17 ile verilmiştir (Aslan, 1997);

$$
\Delta D=\left(\frac{t_{c}}{5}\right)
$$

Mockus yöntemine ait değerleri bulmak için aşağıdaki işlem sırası takip edilir. Geçiş süresi " $t_{c}$ " Eş. 18 ile hesaplanır;

$$
t_{c}=0.00032 *\left(\frac{L_{h}^{0.77}}{S^{0.385}}\right)
$$

S: Drenaj alanının ortalama eğimi (\%), Lh: Drenaj alanının hidrolik uzunluğudur (m). Taşkını oluşturan yağıșın süresi (D) Eş. 19 ile hesaplanır;

$$
D=2 * t^{1 / 2}
$$

Bulunan toplam yağış süresinden sağanak süresi $(\Delta D)$ Eş. 20 ile hesaplanır;

$$
\Delta D=\left(\frac{t_{c}}{5}\right)
$$

Buradan pik debiye ulaşma süresi " $t_{p}$ " Eş. 21 ile hesaplanır;

$$
t_{p}=0.5 * \Delta D+0.6 * t_{c}
$$

Daha sonra tașkın sönümlenme süresi tr Eș. 22 ile hesaplanır;

$$
t_{r}=H_{c} * t_{p}
$$

Burada $\mathrm{H}_{c}$, havza karakteristiklerine göre 1 ile 2 arasında değișen bir katsayıdır. Bu işlemlerden sonra 1 mm'lik yağışın oluşturacağı debi Eş. 23 yardımıyla ile hesaplanır (Çavdar, 1996).

$$
q_{p}=\frac{(K * A)}{t_{p}}
$$

Burada K: 0.21 ile 1.60 arasında değișen havza katsayısıdır. Daha sonra bulunan $\mathrm{q}_{\mathrm{p}}$ değeri maksimum yağış yüksekliği değeri $\left(h_{a}\right)$, ile çarpılarak taşkın debisi $\left(Q_{p}\right)$ bulunur (Eş. 24).

$$
Q_{p}=q_{p} * h_{a}
$$

\subsubsection{DSİ sentetik birim hidrograf yöntemi}

DSİ sentetik metodu $1000 \mathrm{~km}^{2}$ ye kadar olan drenaj alanları için kullanılır. Daha büyük drenaj alanlarına geçildiğinde bu alanlar, $1000 \mathrm{~km}^{2}$ den daha küçük alanlara ayrlarak birim hidrograflar elde edilir. Birim hidrografı elde edilecek olan akarsu arazisinin drenaj alanı (havza alanı) topografik haritalardan hesap edilir. Daha sonra akarsuyun en uzun kolu haritadan ölçülür ve 
drenaj alanı merkezinin en uzun akarsu kolu üzerindeki izdüşümü ile proje kesiti arasındaki mesafe belirlenir. DSİ sentetik metodun uygulanmasına başlanılırken öncelikle arazinin harmonik eğim hesabının yapılması gerekir. Bunun için akarsu membasından başlanarak proje kesitine uyarak yükseklikler ve mesafeler yazılır. Daha sonra toplam uzunluk 10 eşit parçaya bölünerek harmonik eğim (S) hesabı yapılır (Eş. 25). Harmonik eğim bulunduktan sonra Havza parametresi Eş. 26 ile hesaplanır (Demir, 2020).

$$
\begin{aligned}
& S=\left(\frac{10}{\sum \frac{1}{\sqrt{S}}}\right) \\
& \frac{L^{*} L_{c}}{\sqrt{S}}
\end{aligned}
$$

L: Dere uzunluğu, Lc: Havzanın ağırlık merkezinden akarsuya inilen dikmenin akarsuyun kestiği noktadan havza çıkış noktasına olan mesafesi $(\mathrm{km})$ drenaj alanverim grafiğinden verim $\left(q_{p}\right)$ bulunur. " $q_{p}$ ": iki saat devam eden ve havza üzerinde $1 \mathrm{~mm}$ 'lik akıș meydana getiren bir yağışın taşkın debisinin en yüksek değere

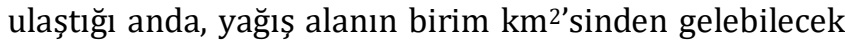
debiyi göstermektedir. Birim hidrograf pik debisi Eş. 27 ile hesaplanır $\left(Q_{p}\right)$.

$$
Q_{p}=A^{*} q_{p} * 10^{-3}\left(\mathrm{~m}^{3} / \mathrm{s} / \mathrm{mm}\right)
$$

Burada, A: Havza alanı, $\mathrm{V}_{\mathrm{b}}$ : ha=1 mm'lik akıș için birim hidrograf hacmi

$$
V_{b}=A^{*} h_{a} * 10^{-3}\left(\mathrm{~m}^{3}\right)
$$

Hidrografın devam süresi T (saat);

$$
T=\frac{3.65 * V}{Q}
$$

Hidrografın yükselme zamanı $\left(\mathrm{T}_{\mathrm{p}}\right)$ Eş. 30 ile hesaplanır.

$$
T_{p}=\frac{T}{5} \text { (saat) }
$$

\subsection{Taşkın Modellemesi}

\subsubsection{FLO-2D}

O’Brien tarafından üretilmiş/geliştirilmiş, 2 boyutlu hidrolik modellemelerin yapıldığ paket programlardan biridir. FLO-2D son yıllarda yapılan taşkın modellemelerinde yaygın olarak kullanılmaktadır. Suyun akıșını zamana bağlı olarak modellemektedir. Bu model, çeşitli boyutlarda tanecikler içeren, ana bileşenleri katı ve su materyallerinin oluşturduğu akımın basitleștirilmiş halini temsil eder (Brien, 2006). Ticari bir yazılım olan
FLO-2D, ikinci dereceden reolojik yasaya dayanan, çamur ve moloz akışının sonlu farklar yöntemiyle simülasyonunu yapan programdır. FLO-2D, bir viskoplastik akışkanı temsil eden Herschel-Bulkley reolojisini de içeren, sonlu hacim modelidir. Bu reolojik model, yeterli miktarda kil içeriğine sahip, çamurlu tipteki moloz akışını modelleyebilmektedir (Hsu ve ark., 2010). FLO-2D, tam dinamik dalga momentum ve süreklilik denklemlerini sonlu farklar yöntemi kullanarak kare ızgara elemanlar için çözmektedir. Böylece taşkın dalgasının ızgara elemanlar sisteminde iki boyutlu yayılımını hesap etmektedir (Elçi ve ark., 2017). Temel denklemler Eș. 31-33'te yer almaktadır.

$$
\begin{aligned}
& \frac{\partial U}{\partial t}+\frac{\partial F}{\partial x}+\frac{\partial G}{\partial y}=S \\
& U=\left[\begin{array}{l}
h \\
h_{u} \\
h_{v}
\end{array}\right], \quad F=\left[\begin{array}{l}
h_{u} \\
h_{u u} \\
h_{u v}
\end{array}\right], \quad G=\left[\begin{array}{l}
h_{v} \\
h_{u v} \\
h_{v v}
\end{array}\right] \\
& S=\left[\begin{array}{c}
0 \\
-g h \frac{\partial Z}{\partial x}-g \frac{n^{2} u \sqrt{u^{2}+v^{2}}}{h^{\frac{1}{3}}} \\
-g h \frac{\partial Z}{\partial y}-g \frac{n^{2} v \sqrt{u^{2}+v^{2}}}{h^{\frac{1}{3}}}
\end{array}\right]
\end{aligned}
$$

Burada, u: x-yönünde akım hızı; v: y-yönünde akım hızı; g: yerçekimi ivmesi; h: akım derinliği; Z: su yüzeyi kotu ve n: Manning pürüzlülük katsayısıdır (Tayfur, 2017; Ying ve ark., 2009).

\section{3. ÇALIŞMA ALANI}

Çalışma alanı olarak Samsun merkez ilçe sınırlarında yer alan ve Karadeniz'e dökülen, Mert Irmağı (enlem: $41,279^{\circ}$ ve boylam: $36,352^{\circ}$ koordinatları) seçilmiştir. Çalışma alanı Şekil 2'de gösterilmiștir. Bu ırmak üzerinde altı adet köprü bulunmaktadır (Ulke ve ark., 2017).

Samsun ili Canik ilçesinde, 03.07.2012 Salı gecesi başlayan ve 04.07.2012 Çarşamba sabahına kadar devam eden şiddetli sağanak sebebiyle meydana gelen taşkın sonucun da 14 kişi yaşamını yitirmiş ve büyük maddi hasar meydana gelmiştir. Taşkın sonucunda 1111 konut, 1507 işyeri, 327 depo, 36 kamu binası, 23 ahır ve samanlık zarar görmüştür. Taşkına bağlı olarak SamsunSinop karayolu $30 \mathrm{~cm}$ kalınlığında çamur tabakası ile kaplanmıș ve 3-4 saat ulașıma ara verilmiștir. Șehri doğu batı yönünde bağlayan tramvay hattı da sular altında kalmış ve 6 saat ulaşıma kapanmıştır (DSİ, 2017). Bu çalıșmada incelenen Mert Irmağı ve havzası, Samsun tarihi boyunca kente sağladığı içme ve sulama suyu açısından önemli bir yere sahiptir. Ayrıca 3 Temmuz 2012 tarihinde Samsun'da yaşanan taşkında can ve mal kaybının yüksek oranda olduğu için de uygulama alanı olarak tercih edilmiștir. 

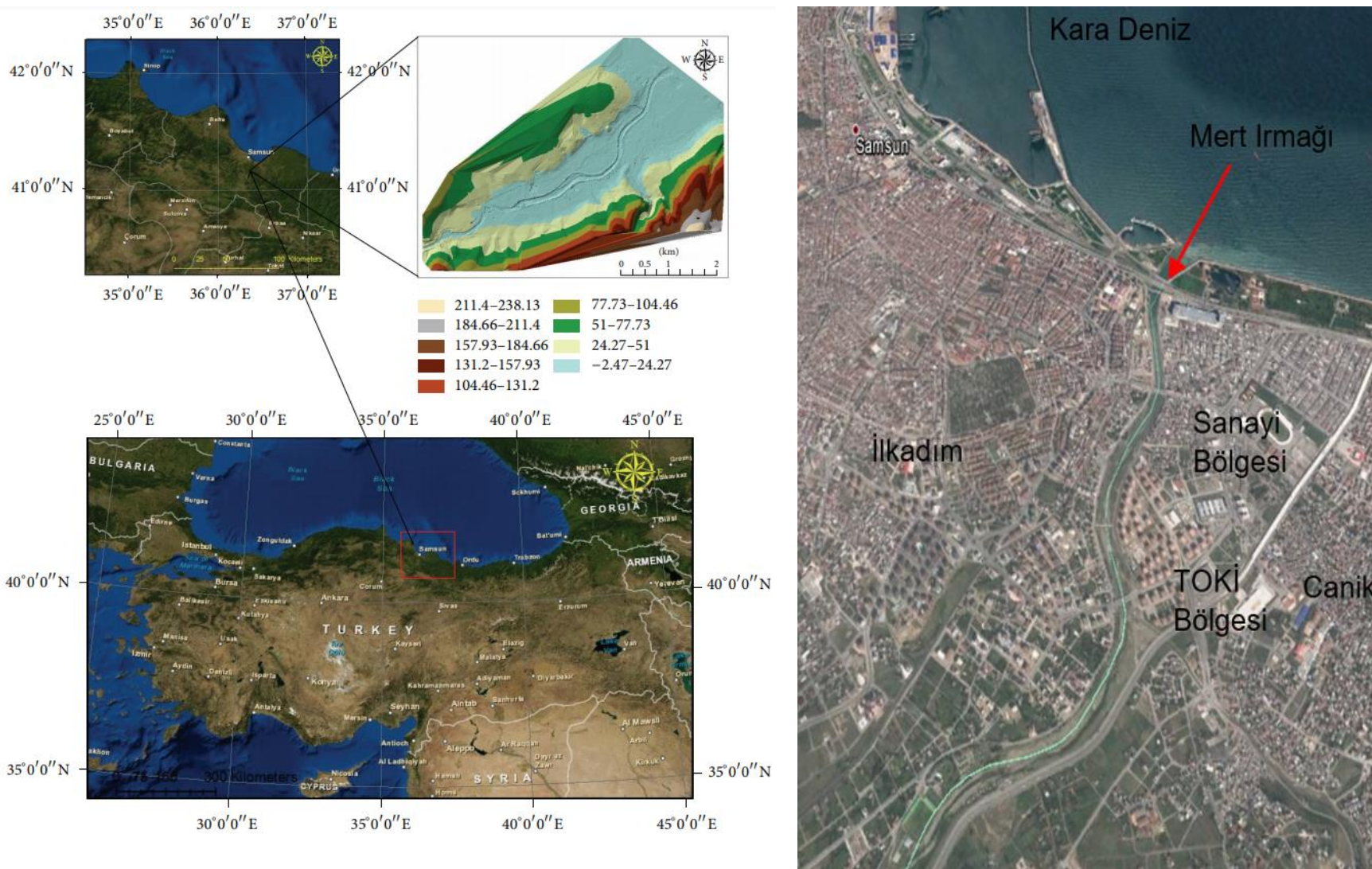

Şekil 2. Çalışma alanı (Demir \& Kisi, 2016)

\section{Olasılık Dağılım Fonksiyonları Yardımıyla Taşkın Tekerrür Debilerinin Hesabı}

Mert Irmağı üzerinde 2007 yılında kurulan 2262 numaralı (Mert Irmağı-Çorak) Elektrik İşleri Etüt İdaresi'ne ait (EIE) bir adet akım gözlem istasyonu (AGI) bulunmaktadır. Taşkın pik debileri, akım verilerine Olasılık Dağılım Fonksiyonları (ODF), Noktasal ve Bölgesel Taşkın Frekans Analiz (NTFA, BTFA) yöntemi uygulanarak elde edilmiştir. Çalışmada en çok tercih edilen 5 farklı OYF'nu denenmiștir. Bunlar; Normal dağlım, Log-Normal Tip-2, Log-Normal Tip-3, Gumbel, Log-Pearson Tip-3, Pearson dağılımlarıdır. Taşkın debilerinin hesabında OYF'nın kullanımı analitik yöntem olarak da tanımlanmaktadır (Beden, 2019). NTFA ve BTFA'da ise Mert Irmağı AGİ verisinin yetersiz olması nedeniyle, akım gözlemleri açısından Mert Irmağı AGI'ye benzer karakteristik özellikleri olan D14A014 numaralı Kürtün AGİ, D14A042 numaralı Abdal Irmağı AGİ, D14A081 numaralı Dereçam Deresi Güven Barajı AGİ, D15A026 numaralı Engiz Deresi Ballıca AGİ ve E22A045 numaralı Terme Çayı Gökçeli AGİ kullanılmıştır. Taşkın tekerrür debilerinin hesabında öncelikle akarsularda yapılan akım ölçümlerden elde edilen analizler tercih edilmektedir. Fakat akarsuların hepsinde ölçüm ne yazık ki yapılamamaktadır. Bașka bir ifade ile istatistiksel olarak anlamlı analizler yapabilmek için yeterli uzunlukta veri bulunmamaktadır. Çalışılan alanı temsil edebilmesi için ilgili AGİ'nin uzun gözlem sürelerine sahip olması gerekmektedir. Genellikle 30 yıldan az ölçümü olan AGi'lerin istatistiksel analizinde küçük örneklem dağılımları kullanılmalıdır. Bu istasyonların değerlendirilmesinde büyük örneklerde uygulanan (30'dan büyük verisi bulunan) yöntemleri kullanmak hatalı bir yaklaşımdır (Bayazıt, 1981; DSİ, 2012). Bu açıdan bakıldığında Mert Irmağı'nın verileri yeterli değildir. Ancak çalıșmada diğer yöntemlerle karşılaștırmak için Mert Irmağı AGİ'ye ait YAMA (Yıllık Anlık Maksimum Akım)'ların taşkın tekerrür analizleri yapılmıştır. Taşkın tekerrür debileri Tablo 2'deki gibi elde edilmiştir. Verilerin hangi dağılıma uydukları ise Kolmogorov-Smirnov (KS) testi ile belirlenmiștir (Tablo 3). Tablolarda koyu yazılan rakamlar dağlım tipi için en yüksek değerleri, italik ve altı çizgili belirtilen rakamlar ise en düșük değerleri göstermektedir.

Dağılım fonksiyonları güven aralığının \%90, \%95 ve \%99'luk kısımlarında KS testi uygulanmıştır. Test sonuçları Tablo 3'te yer almaktadır.

\subsubsection{Yağış Verilerinin ODF Değerlendirmesi}

Mert Irmağı Havzası, 17030-Samsun Bölge DMI'den, 1125-Çakıralan ve 14-017-Mazlumoğlu DSİ gözlem istasyonundan etkilenmektedir (Demir, 2020). İstasyonların Thiessen poligonları Şekil 3'te yer almaktadır. Thiessen oranları ve gözlem süreleri Tablo 4 'te verilmiştir. 
Tablo 2. Mert Irmağı için hesaplanan taşkın tekerrür debileri

\begin{tabular}{lccccccc}
\hline \multirow{2}{*}{$\begin{array}{l}\text { Dağıllım } \\
\text { Tipi }\end{array}$} & 2 & 5 & 10 & 25 & 50 & \multicolumn{7}{c}{ Dönüș Aralığı (yıl) } \\
\cline { 2 - 8 } N & $\mathbf{1 4 3 . 2 5}$ & 266.29 & 330.62 & $\underline{399.26}$ & $\underline{443.51}$ & $\underline{483.36}$ & $\underline{563.56}$ \\
LN-T2 & 100.26 & 204.13 & 296.03 & 440.14 & 568.40 & 715.59 & 1137.47 \\
LN-T3 & 104.97 & 224.03 & 317.40 & 451.16 & 561.60 & 681.37 & 996.93 \\
P-T3 & 85.75 & 203.35 & 316.75 & 476.22 & 602.88 & 733.00 & 998.70 \\
LP-T3 & $\underline{93.59}$ & $\underline{171.09}$ & $\underline{262.87}$ & 456.27 & $\mathbf{6 8 7 . 1 7}$ & $\mathbf{1 0 2 9 . 8 1}$ & $\mathbf{2 2 9 9 . 0}$ \\
G & 123.14 & $\mathbf{2 9 4 . 4 0}$ & $\mathbf{4 0 7 . 7 8}$ & $\mathbf{5 5 1 . 0 4}$ & 657.32 & 762.82 & 1006.6 \\
\hline
\end{tabular}

Tablo 3. Mert Irmağı KS testi sonuçları

\begin{tabular}{|c|c|c|c|c|c|c|c|}
\hline \multirow{2}{*}{$\begin{array}{l}\text { Dağılım } \\
\text { Tipi }\end{array}$} & \multirow{2}{*}{$\begin{array}{c}\text { Teorik } \\
\text { P }\end{array}$} & \multirow{2}{*}{$\underset{P}{\text { Amprik }}$} & \multirow{2}{*}{$\begin{array}{l}\text { Maksimum } \\
\text { P } \Delta_{\max }\end{array}$} & \multirow{2}{*}{$\begin{array}{c}\text { P deki } \\
\text { Gözlem }\end{array}$} & \multicolumn{3}{|c|}{ Anlamlılık Yüzdeleri } \\
\hline & & & & & $\% 90$ & $\% 95$ & $\% 99$ \\
\hline $\mathrm{N}$ & 0.573 & 0.833 & 0.261 & 170.0 & Kabul & Kabul & Kabul \\
\hline LN-T2 & 0.688 & 0.167 & 0.145 & 66.3 & Kabul & Kabul & Kabul \\
\hline LN-T3 & 0.732 & 0.083 & 0.185 & 50.8 & Kabul & Kabul & Kabul \\
\hline P-T3 & 0.340 & 0.167 & 0.173 & 66.3 & Kabul & Kabul & Kabul \\
\hline LP-T3* & 0.010 & 0.083 & 0.073 & 50.8 & Kabul & Kabul & Kabul \\
\hline $\mathrm{G}$ & 0.327 & 0.083 & 0.243 & 50.8 & Kabul & Kabul & Kabul \\
\hline
\end{tabular}

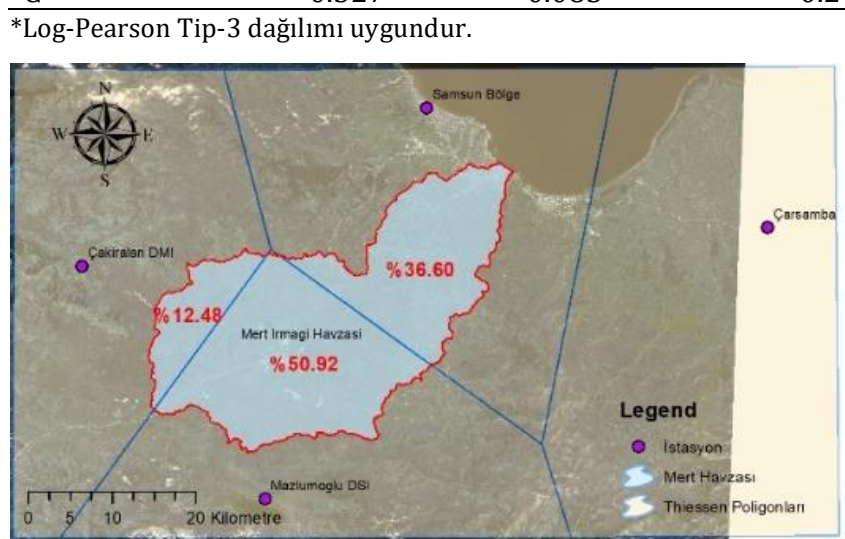

Şekil 3. Çalışma alanı

Tablo 4. Yağıș istasyonlarının Thiessen oranları ve gözlem süreleri

\begin{tabular}{lcccc} 
İstasyon Adı & $\begin{array}{c}\text { Thiessen } \\
\text { Oranı }(\%)\end{array}$ & $\begin{array}{c}\text { Enlem } \\
\left({ }^{\circ} \mathrm{K}\right)\end{array}$ & $\begin{array}{c}\text { Boylam } \\
\left({ }^{\circ} \mathrm{D}\right)\end{array}$ & $\begin{array}{c}\text { Gözlem } \\
\text { Süresi }\end{array}$ \\
\hline $\begin{array}{l}\text { Samsun } \\
\text { Bölge MGİ }\end{array}$ & 36.60 & 41.34 & 36.25 & $\begin{array}{c}1960-2018 \\
(59 \mathrm{yll})\end{array}$ \\
$\begin{array}{l}\text { Mazlumoğlu } \\
\begin{array}{l}\text { DSI } \\
\text { Çakıralan }\end{array}\end{array}$ & 50.92 & 40.92 & 36.02 & $\begin{array}{c}1959-2012 \\
(48 \mathrm{yll})\end{array}$ \\
DMİ & 12.48 & 41.17 & 35.76 & $\begin{array}{c}1969-1988 \\
(18 \mathrm{yl})\end{array}$ \\
\hline
\end{tabular}

Günlük maksimum yağıșlar ve ODF yardımıyla 2, 5, $10,25,50,100$ ve 500 yıllık tekerrürlü günlük maksimum yağışlar hesaplanmıştır (Şekil 4).

\subsubsection{Noktasal ve Bölgesel Taşkın Frekans Analizi}

NTFA'da, Mert Irmağı havzasına yakın 5 istasyon (D14A014 numaralı Kürtün AGİ, D14A042 numaralı Abdal Irmağı AGİ, D14A081 numaralı Dereçam Deresi Güven Barajı AGİ, D15A026 numaralı Engiz Deresi Ballıca AGİ ve E22A045 numaralı Terme çayı Gökçeli AGİ) YAMA verilerine uygun dağılım fonksiyonuna göre belirlenmiş taşkın tekerrür debileri Mert Irmağına taşınmıştır. Taşıma sirasında $Q_{\text {ARANAN }}=\left(A_{\text {ARANAN }} / A_{\text {TAŞINAN }}\right)^{n}$ denklemi kullanılmıştır (DSİ, 2012). Denklemde yer alan "n" ifadesi havzadan havzaya değișen bir kat sayı olup Karadeniz Bölgesi için 2/3'tür (Özdemir, 1978). İstasyonlara ait bilgiler Tablo 5'te yer almaktadır. Taşınan tekerrür debileri ise Tablo 6'da verilmiștir.

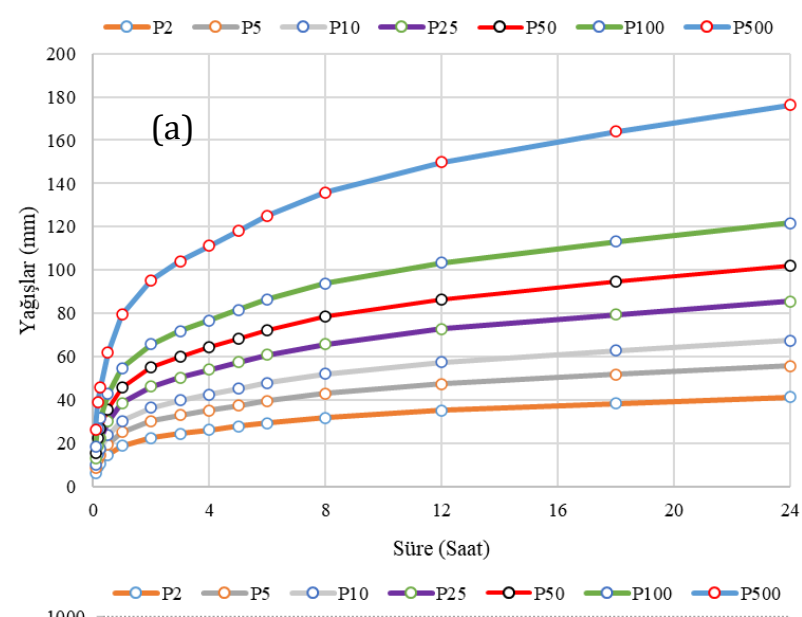

(b)

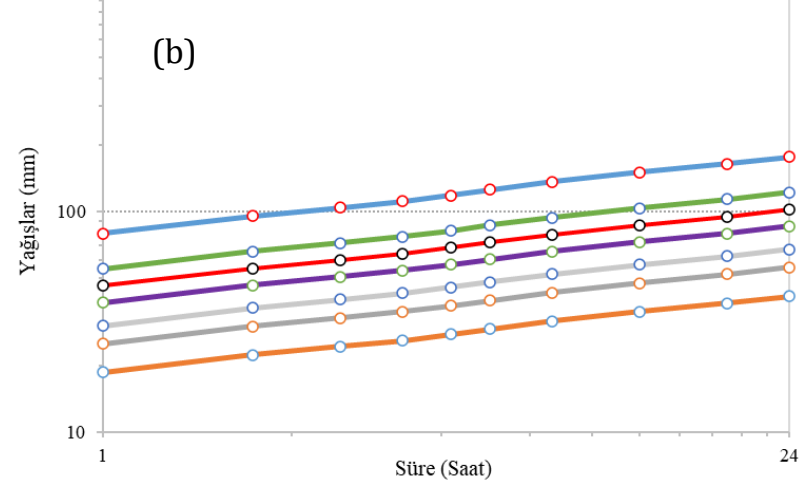

Şekil 4. Yağış-Süre-Tekerrür eğrileri (a), Logaritmik eksen takımında Yağış-Süre-Tekerrür grafiği (b)

$\mathrm{Bu}$ çalışmada Bölgesel Taşkın Frekans Analiz (BTFA) uygulaması noktasal frekans analizinde kullanılan istasyonlar yardımıyla yapılmıştır. BTFA'da "index taşkın yöntemi” kullanılmıştır (Şorman, 2004). Tablo 5'teki istasyonlara ait taşkın debileri ODF ve KS testi uygulanarak elde edildikten sonra her istasyonun kendi $\mathrm{Q}_{2}$ taşkın debisine bu değerler bölünerek boyutsuz debiler elde edilmiştir. Boyutsuz değerlerin ortalaması alınarak istasyonlar için $\mathrm{Q}_{\mathrm{T}} / \mathrm{Q}_{2}$ değerleri elde edilmiştir. Ardından $\mathrm{Q}_{10} / \mathrm{Q}_{2}$ oranına göre homojenlik analizi yapılmış ve tüm istasyonların homojen sınırlar arasında kaldığı görülerek, tüm istasyonların $Q_{2}$ - yağış alanına 
göre zarf eğrisi çizilmiştir. Homojenlik testlerine giren akım gözlem istasyonlarının on yıldan fazla aynı dönem ölçümleri olmalıdır (DSİ, 2012). Aynı dönemde yeteri kadar verisi bulunmayan akım gözlem istasyonlarının bölgesel taşkın frekans analiz yapılmamalıdır. Mert
Havzası'na $\left(A=814 \mathrm{~km}^{2}\right)$ karşılık gelen $Q_{2}$ değeri (155 $\mathrm{m}^{3} / \mathrm{sn}$ ) okunmuştur (Şekil 5). Bu değer $\mathrm{Q}_{\mathrm{T}} / \mathrm{Q}_{2}$ değerleri ile çarpılarak bölgesel taşkın debileri her bir tekerrür süresi için ayrı ayrı bulunmuştur (Tablo 7).

Tablo 5. İstasyonlara ait bilgiler

\begin{tabular}{|c|c|c|c|c|c|c|}
\hline İstasyon No & İstasyon Adl & Enlem $\left({ }^{\circ} \mathrm{K}\right)$ & Boylam ( $\left.{ }^{\circ} \mathrm{D}\right)$ & $\begin{array}{l}\text { Yükseklik } \\
\text { (m) }\end{array}$ & $\begin{array}{c}\text { Yağış Alanı } \\
\left(\mathrm{km}^{2}\right)\end{array}$ & Gözlem Süresi \\
\hline E22A062 & Mert Irmağl & 41.24 & 36.28 & 44 & 740 & $07-15$ \\
\hline D15A026 & Engiz Deresi & 41.48 & 36.07 & 15 & 151.4 & $65-15$ \\
\hline D14A014 & Kürtün Çayı & 41.23 & 36.19 & 140 & 259 & $65-15$ \\
\hline D14A042 & Abdal Irmağl & 41.22 & 36.57 & 3 & 502.5 & $68-91$ \\
\hline D14A081 & Dereçam Deresi & 41.08 & 35.96 & 652 & 9.4 & $73-15$ \\
\hline $\mathrm{E} 22 \mathrm{~A} 045$ & Terme Cayı & 41.08 & 36.83 & 66 & 232.8 & $69-15$ \\
\hline
\end{tabular}

Tablo 6. NTFA ile elde edilen Mert Irmağı Tekerrür debileri

\begin{tabular}{llllllll}
\multirow{2}{*}{ No } & \multicolumn{1}{c}{ Yineleme ylllarl } \\
\cline { 2 - 8 } & \multicolumn{1}{c}{2} & 5 & \multicolumn{1}{c}{10} & \multicolumn{1}{c}{25} & \multicolumn{1}{c}{50} & 100 & 500 \\
\hline D15A026 & 201.8 & 392.5 & 561.6 & 829.0 & 1070.2 & 1351.1 & 2079.1 \\
D14A014 & 92.9 & 204.0 & 307.4 & 475.5 & 629.9 & 810.3 & 1287.0 \\
D14A042 & 143.2 & 282.9 & 402.3 & 584.0 & 741.7 & 918.0 & 1356.9 \\
D14A081 & 63.7 & 146.4 & 224.2 & 351.4 & 467.9 & 603.5 & 960.6 \\
E22A045 & 531.4 & 892.9 & 1181.9 & 1604.4 & 1960.8 & 2355.6 & 3308.2 \\
\hline
\end{tabular}

\section{Mert Irmağı Civarında Bölgesel Taşkın Analizinde Kullanılan Akım Gözlem İstasyonlarının $\left(Q_{\mathrm{T}} / \mathbf{Q}_{2}\right)$} Bölgesel Taşkın Frekans Grafiği-Taşkın Zarfı

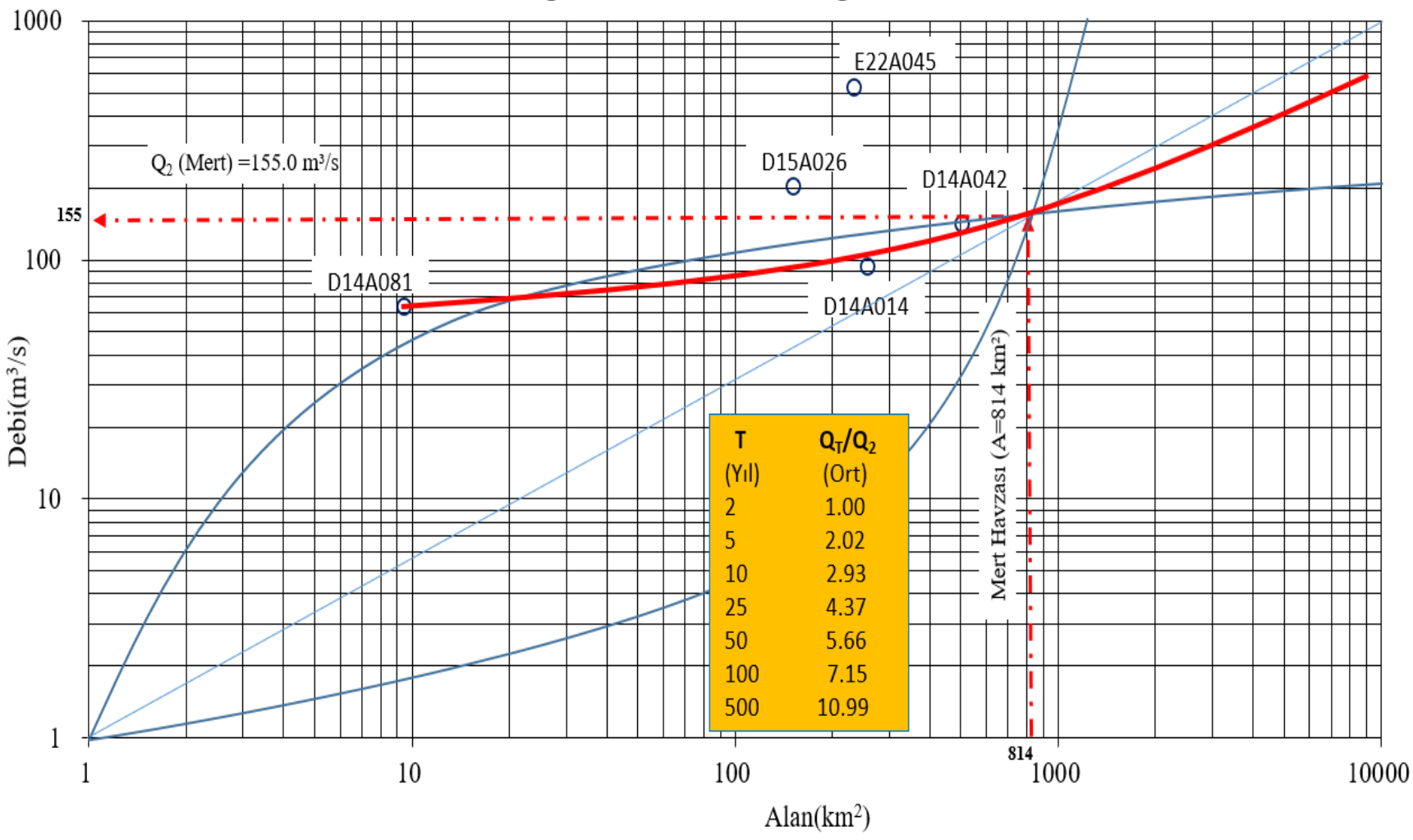

Şekil 5. BTFA Debi-Alan grafiği

Tablo 7. Tekerrür debileri özet tablo

\begin{tabular}{lccccccccc}
\hline \multirow{2}{*}{$\begin{array}{l}\text { Tekerrür } \\
\text { Debisi }\end{array}$} & \multicolumn{1}{c}{ Noktasal Tașkın Frekans Analizi } \\
\cline { 2 - 9 } & D15A026 & D14A014 & D14A042 & D14A081 & E22A045 & BTFA & Mockus & $\begin{array}{c}\text { DSI } \\
\text { Sentetik }\end{array}$ & Snyder \\
\hline $\mathrm{Q}_{2}$ & 201.8 & 92.9 & 143.2 & 63.7 & 531.4 & 155 & 337 & 295 & 312 \\
$\mathrm{Q}_{5}$ & 392.5 & 204 & 282.9 & 146.4 & 892.9 & 313 & 502 & 433 & 464 \\
$\mathrm{Q}_{10}$ & 561.6 & 307.4 & 402.3 & 224.2 & 1181 & 454 & 639 & 548 & 591 \\
$\mathrm{Q}_{25}$ & 829 & 475.5 & 584 & 351.4 & 1604 & 677 & 855 & 729 & 790 \\
$\mathrm{Q}_{50}$ & 1070 & 629.9 & 741.7 & 467.9 & 1960 & 877 & 1053 & 895 & 973 \\
$\mathrm{Q}_{100}$ & 1351 & 810.3 & 918 & 603.5 & 2355 & 1108 & 1294 & 1097 & 1195 \\
$\mathrm{Q}_{500}$ & 2079 & 1287 & 1356 & 960.6 & 3308 & 1703 & 1962 & 1659 & 1811 \\
\hline
\end{tabular}




\subsection{Sentetik Yöntemler}

Mert Irmağı'nın havza alanı A:814 $\mathrm{km}^{2}$, havza uzunluğu L: 73.09 km, Lc: 35.9 km, eğimi S: 0.01029'dir. Yağıș Alanı dağılım katsayısı (YADK) 0,857, CNII ve CNIII 95 olarak DSİ'den görüş alınarak belirlenmiștir. 6 saatlik yağış için Samsun Bölge MGI plüvyograf katsayısı 0.814 'tür. 24 saatlik yağışlar plüviyograf katsayılarıyla, YADK ve 1.13 artırım katsayısı ile çarpılarak 6 saatlik yağışa çevrilmiștir. Analizlerde kullanılan günlük maksimum yağış değerleri, günlük (24 saatlik) yağışları temsil edemediği için 1.13 ile çarpılmıştır (Karapınar, 2017). Snyder yönteminde ( $\left.C_{t}\right)$ ve Havza tutma kapasitesi $\left(\mathrm{C}_{\mathrm{p}}\right)$ seçilmelidir. Bu seçim yapılarken zemin durumu dikkate alınır (DSİ, 2017). Çalışmada killi veya kayalık zeminlerde kullanılan $\mathrm{C}_{\mathrm{t}}=1.35$ ve $\mathrm{C}_{\mathrm{p}}=0.69$ değerleri kullanılmıștır. Sentetik yöntemlerle, NTFA ile, BTFA ile elde edilen taşkın tekerrür debileri Tablo 7'de verilmiştir. 0-1000 km arası Mockus, $10-1000 \mathrm{~km}^{2}$ arası DSİ Sentetik ve $1000 \mathrm{~km}^{2}$ den büyük drenaj alanları için Snyder yöntemi, düz eğimsiz alanlarda Mc Math Metodu, $5 \mathrm{~km}^{2}$ den küçük direnaj alanları için Rational metod yöntemi önerilmektedir (Beden, 2019). Mert ırmağ havza alanını 1000 km²'den küçüktür. Mert Irmağı havza alanı Snyder yöntemlerine göre uygun olmasa da bu yöntemin sonuçları DSI sentetik yöntemle karşılaştırılması amacıyla verilmiştir.

Hidrolik modellemelerde tasarım yapılırken havza drenaj alanı büyüklüğüne göre ve BTFA sonuçlarına yakınlı̆̆ı sebebiyle, DSİ Sentetik yönteminin kullanılmasına karar verilmiştir. Bu yöntem birçok araștırmacı tarafından taşkın debileri hesaplamaları yapilırken kabul görmüş bir yöntemdir (Beden, 2019; Denizolgun ve ark., 2018; Kumanlığlu \& Ersoy, 2018; Öztürk, Kaya \& Așkan, 2003).

$\mathrm{Q}_{1000}, \mathrm{Q}_{10.000}$ gibi diğer tekerrür yıllarındaki debileri hesaplamak için literatürde $\mathrm{Q}_{\mathrm{T}}=\mathrm{Q}_{10}+\mathrm{Z}_{\mathrm{T}} \quad\left(\mathrm{Q}_{100}-\mathrm{Q}_{10}\right)$ formülü kullanılmaktadır (DSİ, 2012; Karapınar, 2017). $\mathrm{Q}_{1000}$ için $\mathrm{Z}_{\mathrm{T}}=2.98, \mathrm{Q}_{100}$ için $\mathrm{Z}_{\mathrm{T}}=1.99, \mathrm{Q}_{500}$ için, 1.692 'dir (Chow, 1964). Çalışmada ayrıca $Q_{1000}$ debisini elde etmek için iki farklı yöntem kullanılmıştır. Bunlardan ilki yukarıda yer alan $\mathrm{Q}_{\mathrm{T}}$ eşitliği, ikincisi ise taşkın tekerrürlerinin logaritmik eksen takımlarında oluşturduğu eğriye uydurulan en uygun denklemin uzatılması ve ilgili tekerrürlerde taşkın debilerinin bulunması şeklindedir. Her iki yöntem ile tahmin edilen pik debiler karş̧laștırılmış ve büyük olanı seçilmiştir (DSİ, 2012). DSİ Sentetik yöntemine göre daha büyük debiler, tekerrür debileri eğrisinin uzatılmasıyla elde edilen değerler olduğu görülmüş ve modelleme aşamasında bu debilerin kullanılmasına karar verilmiştir. Mert Irmağı'nın DSİ Sentetik yöntemine göre $\mathrm{Q}_{1000}$ debisi $2216.3 \mathrm{~m}^{3} / \mathrm{s}$ olarak elde edilmiştir.

\subsection{Baz Akım Hesabı}

Baz akımı, bir akarsuyun taşkın zamanındaki ortalama sarfiyatını ifade eder. Drenaj alanının durumuna göre ve iklim şartlarına göre baz akımı, yıl boyunca belirli sınırlar arasında değişir. Genellikle kar erimelerinin ve yağışlarının fazla olduğu bölgelerde kış ve ilkbahar aylarında yüksek, yaz ve sonbahar aylarında düşük olur. Çok yağış alan ve kar erimesinin uzun süre devam ettiği drenaj alanlarında, baz akımın taşkınlara etkisi önemlidir. Bu bakımdan sentetik metotlarla hesap edilen yüzeysel akışın meydana geldiği taşkınlara baz akımın eklenmesi gerekmektedir (Özdemir, 1978). Bu çalışmada baz akım, akım-sürek eğrisinin zamanının \%95'inde meydana gelen akımın baz akım olarak alınmıştır. Aylık ortalama akım verilerine ait gidiş grafiği Şekil 6'da yer almaktadır.

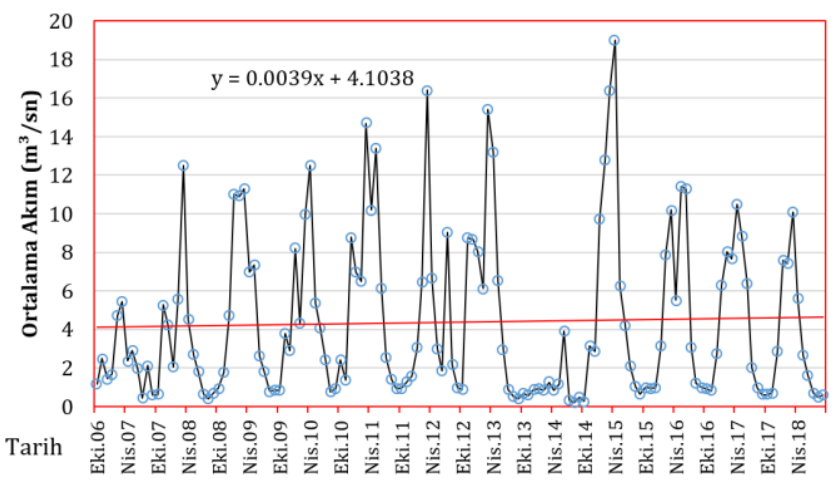

Şekil 6. Aylık ortalama akım verilerinin gidiş grafiği

Akım sürek eğrisi ise veri sayısı (n) ve mertebe (m)'ye bağlı olarak güven (g) değerleri yüzdesel olarak hesaplanır. Her bir mertebe için güven değeri Eş. 34 yardımıyla elde edilir (Şen, 2009).

$$
g=\frac{m}{n+1}
$$

Güven değerleri her bir mertebe için elde edildikten sonra akım-güven veya akım-sürek grafiği çizilir. Mert Irmağına ait 2007-2018 yılları arası akım-sürek eğrisi Şekil 7'de yer almaktadır.

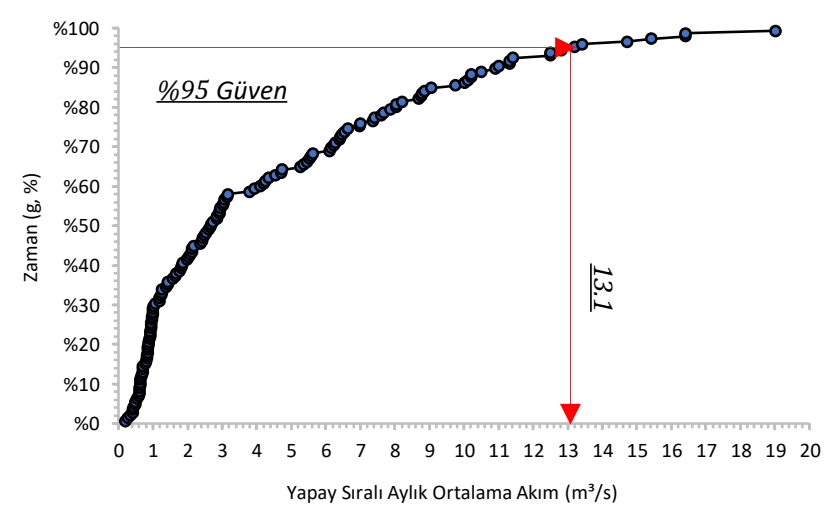

Şekil 7. Baz akım

Elde edilen $13.1 \mathrm{~m}^{3} / \mathrm{s}^{\prime}$ lik baz akımı, sentetik metotlarla hesaplanan yüzeysel akıştan meydana gelen hidrograflara, hidrograf tabanı boyunca sabit olarak eklenir (Şen, 2009).

\subsection{Manning değerlerinin elde edilmesi}

Taşkın debilerinin belirlenmesinden sonra bir modellemenin yapılabilmesi için çalışılan bölgeye ait Manning pürüzlük katsayılarının belirlenmesi gerekmektedir. Bu çalışmada uydu görüntüsü-uzaktan algılama teknikleri ve ırmak yatağından alınan numunelerle ve COWAN yöntemine göre Manning değerleri belirlenmiștir. Çalışmanın bu bölümü ayrı bir 
makale olarak çalışılmıştır. Ayrıntılar için (Demir \& Keskin, 2019) incelenebilir. Elde edilen nihai Manning haritası aşağıda Şekil 8'de yer almaktadır (Demir, 2020).

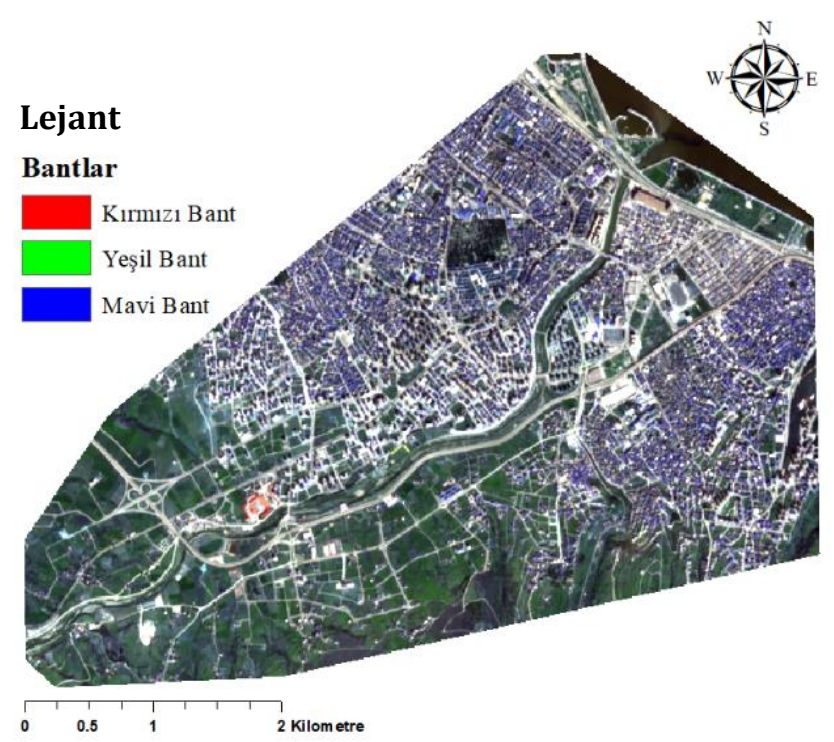

(a)

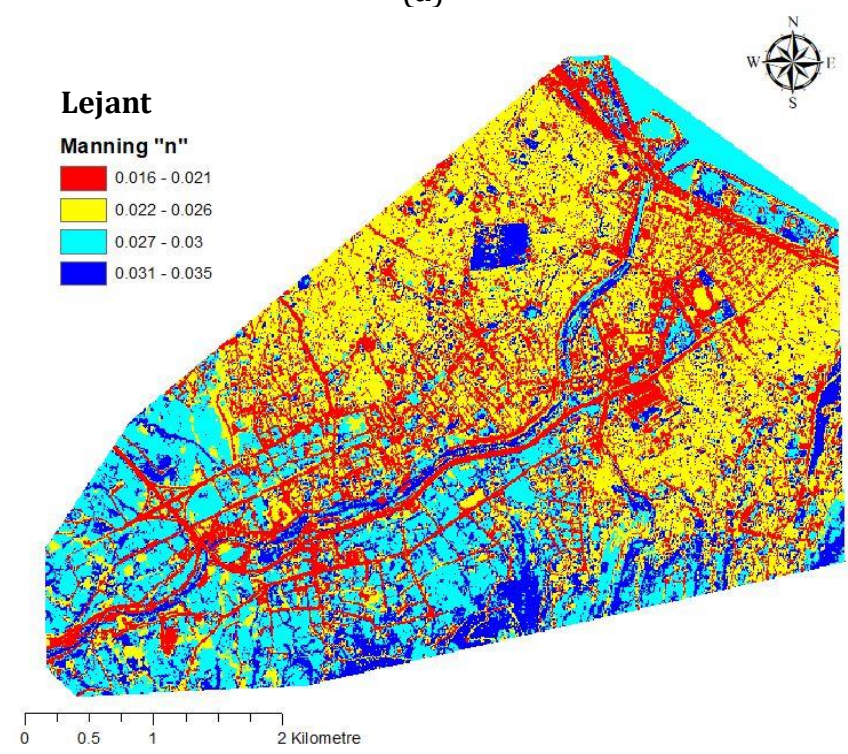

(b)

Şekil 8. Sinıflandırma öncesi uydu görüntüsü (a), Sinıflandırma sonrası elde edilen Manning haritası (b)

\subsection{Taşkın Modellemesi}

Tekerrür debilerine ait taşkın değerleri belirlendikten sonra (Tablo 8) haritalama işlemi için veriler FLO-2D Paket programının alt yazilımı olan Mapper++ köprü programları kullanılarak tüm bilgiler ArcGIS'e aktarılmıștır. Böylece belli tekerrürlerdeki taşkın yayılım haritaları veya senaryoları $(S ̧ e k i l 9,10)$ elde edilmiştir (Demir \& Keskin, 2020).

Tablo 8. Tașkın tekerrür debileri

\begin{tabular}{lcccc}
\hline $\begin{array}{l}\text { Tekerrür } \\
\text { Periyodu }\end{array}$ & $\mathrm{Q}_{50}$ & $\mathrm{Q}_{100}$ & $\mathrm{Q}_{500}$ & $\mathrm{Q}_{1000}$ \\
\hline $\begin{array}{l}\text { Mert Irmağ } \\
\left(\mathrm{m}^{3} / \mathrm{s}\right)\end{array}$ & 895.2 & 1097.5 & 1659.3 & 2216.3 \\
\hline
\end{tabular}

Şekil 9'da 50 yıl tekerrürlü debisinde ırmağın yatağından taştı̆̆ ve mansap kısmına doğru çalışma alanının sağ kısmında yer alan sanayi bölgesini sular altında bıraktı̆̆ı açıkça görülmektedir. Şekil 9'da $Q_{100}$ ve sonrasında $Q_{500}$ debilerinde suyun nehir kıvrımlarını takip edemeyip nehir kesitinin sağ ve sol kısımlarında 2 metreye varan yüksekliklere ulaștığı görülmektedir. Şekil 10 incelendiğinde sanayi ve TOKİ bölgesinde su yüksekliklerinin 2-3 metreye kadar yükseldiği Yılanlı dere membasına doğru nehir orta kesitlerinde 20 metreye varsan su yükseklikleri görülmektedir. Tüm tașkın senaryolarında tașmalar özellikle nehrin doğusunda kalan bölgede daha fazla görülmektedir. Bunun sebepleri bu bölgenin düşük kotta yerleșmiş olması, nehir kesitinin o bölgelerde yeterli büyüklükte olmamasıdır. Ayrıca taşkın yayılımı 50 ve 100 yıllık tașkın tekerrürlerinde Samsun-Sinop șehirler arası karayolu hattından (mansap bölgesindeki 3. köprü) Karadeniz'e geçememiş ve sanayi bölgesinde havuzlanmaya sebep olmuștur. Q ${ }_{50}$ debisiyle beraber nehrin Karadeniz'e çıkış yaptığı kısımda yer alan tüm köprülerin kesit alanlarının yetersiz olduğu görülmüştür. Gelen debi seviyesi köprüleri üst kotlarını aşmaktadır. Așan su seviyeleri köprülerin yıkılmasına sebep olabilmektedir. $\mathrm{Bu}$ durumu önlemek için köprü tasarımları mümkün olduğunca asma (ayaksız) olarak tasarlanmalıdır. Bu sonuçlar, 1 ve 2 boyutlu taşkın modellemesi yapan MIKE programını kullanan Ulke ve ark. (2017) benzer ve destekleyici niteliktedir. Modellemeye girilen taşkın tekerrür debilerinin çalışma alanında oluşturduğu alanlar sırasıyla 4.38, 4.59, 5.44, $5.93 \mathrm{~km}^{2}$ dir. $\mathrm{Q}_{50}$ debisinden sonra Mert Irmağının mansap kısmında yer alan bölgenin taşkından önemli ölçüde etkilendiği tespit edilmiştir. Q ${ }_{100}$ debisiyle sanayi bölgesinin yaklaşık \%80'i bu taşkından etkilenmiştir. Karadeniz Bölgesi için yapılan çalışmalarda $Q_{50}, Q_{100}$ ve hatta Q500 debilerine yakın debilerde taşkınlar gözlemlenmiştir. $\mathrm{Bu}$ nedenle özellikle Karadeniz Bölgesi'nde $Q_{500}$ taşkın debilerini taşıyabilecek düzenlemeler kentsel alanlarda yapılmalıdır. Bu nedenle özellikle Mert Irmağı'nın Karadeniz'e çıkıs kısımlarında da nehrin sağ ve sol yamaç yüksekliğini artırmak suretiyle kesit düzenlemeleri ve köprü tasarımları yapılmalıdır. Taşkın yayılım haritalarında Samsun-Sinop karayolu ulaşımının sanayi bölgesinde havuzlanmaya sebep olduğunu görülmüș ve bu yol üzerine açılabilecek kanallar taşkın sırasında gelen suyu Karadeniz'e iletmeye yardımcı olacağı düşünülmekte ve önerilmektedir. Ayrıca Mert ırmağının memba kısmında yer alan regülatör taşkın anında görevini yerine getiremeyip suyun kabarmasına ve taşkının şiddetlenmesine sebep olmaktadır. Bu nedenle ilgili su yapısının kaldırılması veya taşkın anında kabarmaya sebebiyet vermeyecek kapak tasarımlarının yapılması önerilmektedir. 

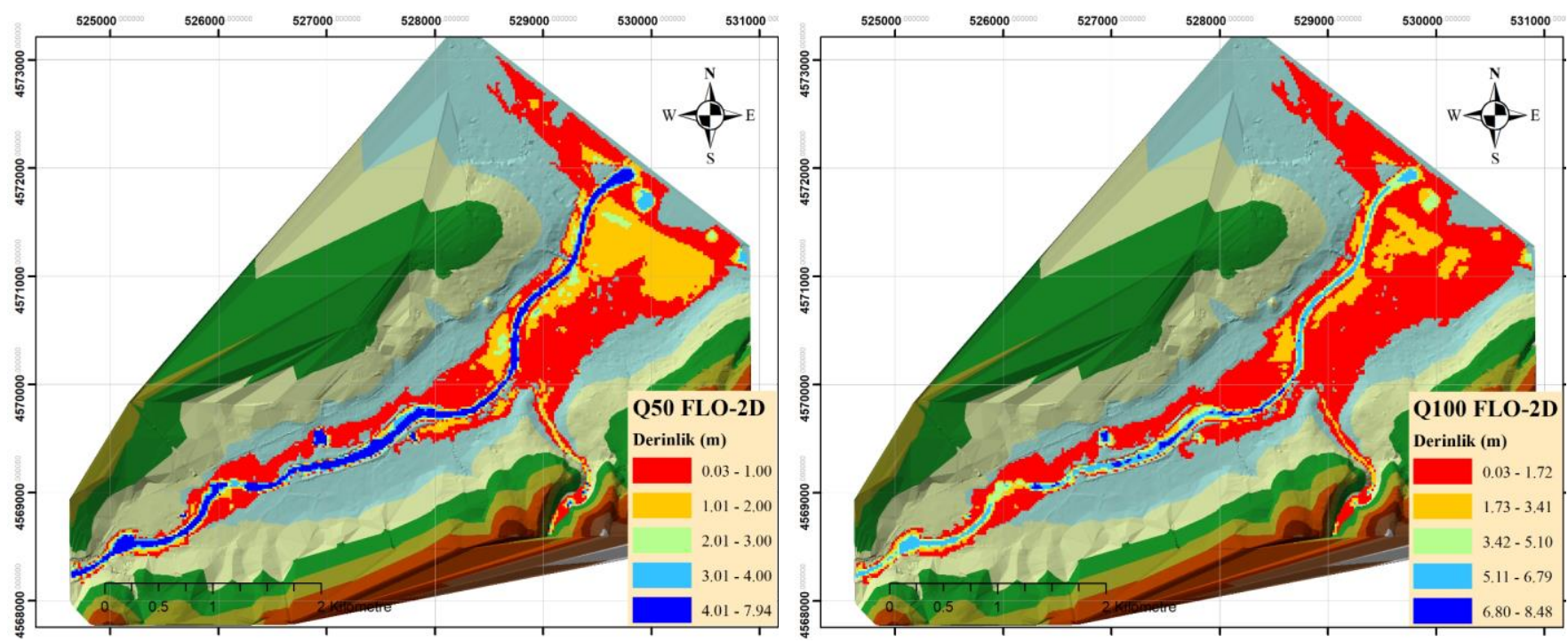

Şekil 9. 50 ve 100 yıllık tekerrürlere sahip debilerin oluşturduğu taşkın derinlik ve yayılım haritaları
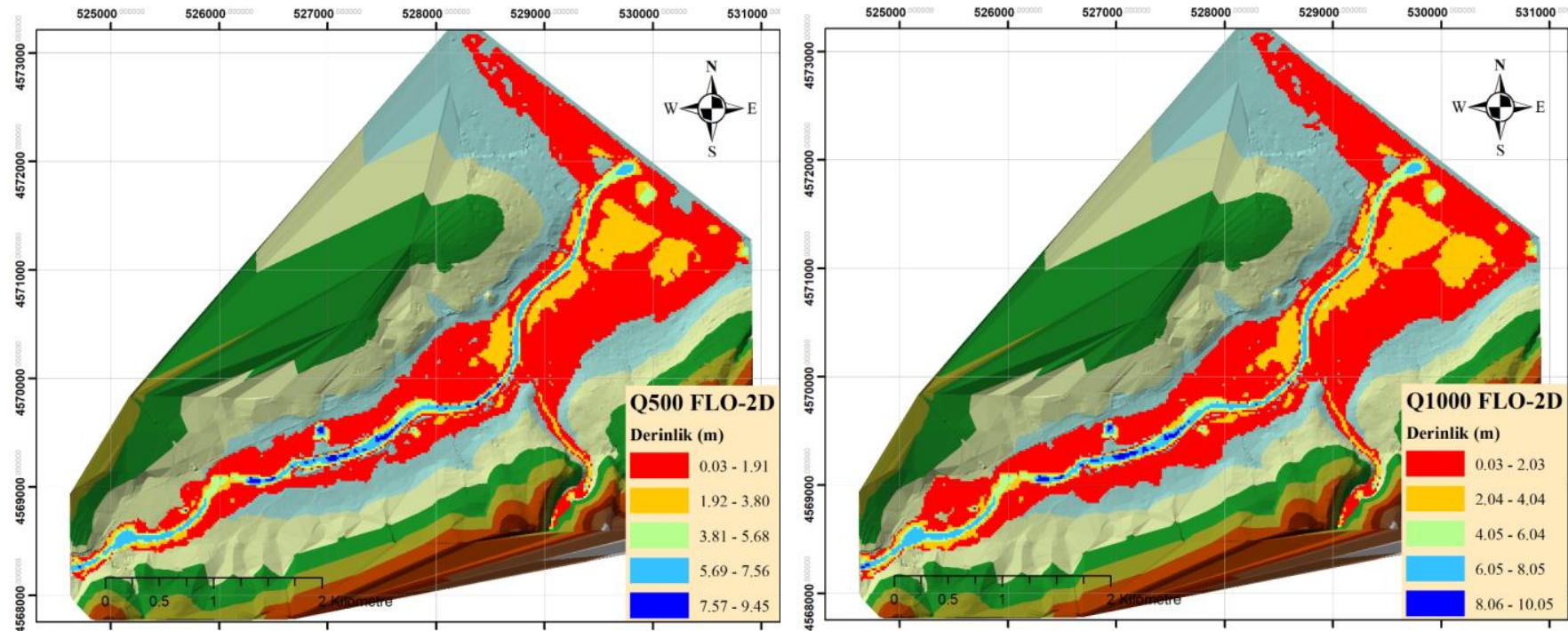

Şekil 10. 500 ve 1000 yıllık tekerrürlere sahip debilerin oluşturduğu taşkın derinlik ve yayılım haritaları

\section{SONUÇLAR}

$\mathrm{Bu}$ çalışmada yeterince akım ölçümü olmayan Samsun, Mert Irmağı taşkın tekerrür debilerinin elde edilmesi ve belli tekerrürlerdeki taşkın hidrograflarının çalışma alanında oluşturduğu taşkın yayılımı modellenmiștir. Taşkın tekerrür debilerinin belirlenmesinde istatistiksel dağılım yöntemler, NTFA, BTFA ve yağış-akış modellemesine dayalı sentetik yöntemler (Mockus, Synder ve DSI Sentetik) kullanılmıştır. Mert Irmağı'nın yeterince akım ölçümü olmadığı için önerilen sentetik yöntemlerin kullanılması gerekliliği karşılaştırma yapılarak tespit edilmiştir. Sentetik yöntemlerde taşkın hidrografları belli tekerrürlerdeki maksimum yağış verilerine en iyi uyum gösteren dağılım istatistiksel dağılımlar kullanılarak belirlenmiştir. Kullanılan istatistiksel dağılımlar; Normal dağılım, Log Normal dağılım, Gumbel dağılımı, LogPearson ve Pearson dağılımlarıdır. En uygun dağılım ise Kolmogorov-Smirnov uygunluk testi ile belirlenmiştir. Havza özelliklerine ve BTFA'ne göre en uygun yöntemin DSİ sentetik yöntemi olduğuna karar verilmiştir. $\mathrm{Bu}$ yönteme göre tekerrür debileri sırasıyla $Q_{50}$ : 895.2, $Q_{100}$ : 1097.5, Q $Q_{500}: 1659.3, Q_{1000}: 2216.3 \mathrm{~m}^{3} / \mathrm{s}$ olarak elde edilmiştir. Ayrıca bu debilere baz akım $13.1 \mathrm{~m}^{3} / \mathrm{s}$ olarak eklenmiştir. Baz akım akım-sürek eğrileri yardımıyla elde edilmiştir. Taşkın debileri FLO-2D programı kullanılarak taşkın modellenmiştir. Modellemede Manning sürtünme katsayıları Cowan yöntemi ve uzaktan algılama teknikleriyle elde edilmiş altlıklar kullanılarak belirlenmiștir. Taşkın yayılım alanları ve su yükseklikleri $Q_{50}, Q_{100}, Q_{500}$ ve $Q_{1000}$ gibi farklı tekerrürlerde incelenmiștir. Modellenen debiler çalıșma alanının \%40-\%80'ini sular altında bırakmıştır. Su altında kalan alanlar ise $4.38 \mathrm{~km}$ 'den 5.93 km'ye kadardır. Taşkının yayıldığı bu alanların oluşturabileceği zararı azaltabilmek için ırmak üzerinde yer alan köprüler ve yapılaşmanın olduğu bölgeler için önerilerde bulunulmuştur.

\section{TEŞEKKÜR}

Bu çalışma Vahdettin Demir'in "Samsun Mert Havzasında Bir ve İki Boyutlu Modeller ile Taşkın Alanlarının Belirlenmesi" başlıklı doktora tez çalıșmasından hazırlanmıştır. 


\section{ARAŞTIRMACILARIN KATKI ORANI}

Vahdettin Demir: Veri toplama, Araștırma, Analiz, Makale yazma ve Düzenleme; Aslı Ülke Keskin: Makale yazma ve Düzenleme.

\section{ÇATIŞMA BEYANI}

Herhangi bir çıkar çatışması bulunmamaktadır.

\section{KAYNAKÇA}

Akgül M A (2018). Sentetik açılklklı radar verilerinin taşkın çalışmalarında kullanılması: Berdan Ovası Taşkını. Geomatik Dergisi, 3, 154-162.

Anlı S A (2006). Giresun Aksu Havzası maksimum akımlarının frekans analizi. Akdeniz Üniversitesi Ziraat Fakültesi Dergisi, 19(1), 99-106.

Aslan B (1997). S.C.S. sentetik birim hidrograf yönteminin türkiye şartlarında uygulanabilirliğinin araştırılması. Yüksek Lisans Tezi. Yıldız Teknik Üniversitesi, Fen Bilimleri Enstitüsü.

Aydın M \& Bağatur T (2016). Nakayasu sentetik birim hidrograf metodunun Türkiye havzalarında kullanılabilirliğinin incelenmesi: Göksu Nehri Havzası örneği. Dicle Üniversitesi Mühendislik Fakültesi Mühendislik Dergisi, 7(3), 377-386.

Bayazıt M \& Önöz B (2008). Taşkın ve Kuraklık Hidrolojisi. Nobel Basımevi. 259 s.

Bayazıt M (1981). Hidrolojide istatistik yöntemler. İstanbul Teknik Üniversitesi matbaası, $166 \mathrm{~s}$.

Bayazıt M \& Yeğen Oğuz B (2013). Mühendisler için İstatistik. Birsen Yayın Dăğıtım Ltd. Şti. 197 s.

Beden N, Ülke A \& Uslu A (2014). İklim değiş̧ikliği ve yeni tasarım esasları, IV. Ulusal Baraj Güvenliği Sempozyumu, 09-11 Ekim 2014, Elazığ, Türkiye.

Beden N (2019). Cevizlidere Havzasının sayısal modelleme sistemlerine dayalı taşkın analizi ve taşkın zararlarının değerlendirilmesi. Doktora Tezi. Ondokuz Mayıs Üniversitesi. Fen Bilimleri Enstitüsü.

Benson M A (1968). Uniform flood-frequency estimating methods for federal agencies. Water Resources Research, 4(5), 891-908.

Bircan H, Karagöz Y \& Kasapoğlu Y (2003). Ki-Kare ve Kolmogorov Smirnov uygunluk testlerinin simulasyon ile elde edilen veriler üzerinde karşılaștırılması. Cumhuriyet Üniversitesi İktisadi ve İdari Bilimler Dergisi, 4(1), 69-80.

Brien K (2006). Pocket guide. FLO-2D Software, Inc. 50 s.

Çavdar S K (1996). İstanbul dereleri için taşkın debilerinin araştırılması. Yüksek Lisans Tezi. İstanbul Teknik Üniversitesi Fen Bilimleri Enstitüsü.

Chow V T (1964). Handbook of applied hydrology. McGraw-Hill. $1495 \mathrm{~s}$.

Demir V \& Kisi O (2016). Flood hazard mapping by using geographic information system and hydraulic model: Mert River, Samsun, Turkey. Advances in Meteorology, 2016. 1-9

Demir V \& Keskin A Ü (2020). Obtaining the manning roughness with terrestrial-remote sensing technique and flood modeling using FLO-2D, a case study Samsun from Turkey, Geofizika, 37(2), 137-156.
Demir V \& Keskin A Ü (2019). Pürüzlülük katsayısının cowan yöntemi ve uzaktan algılama yardımıyla belirlenmesi. Gazi Journal of Engineering Sciences, 5(2), 167-177.

Demir V (2020). Samsun Mert havzasında bir ve iki boyutlu modeller ile taşkın alanlarının belirlenmesi. Doktora Tezi, Ondokuz Mayıs Üniversitesi, Lisansüstü Eğitim Enstitüsü.

Denizolgun F S, Güçlü Y S \& Şen Z (2018). Kuzey Marmara Otoyolunda dere köprüsü tasarımı ve uygulaması : Alemdağ dere köprüsü örneği. Journal of Balıkesir University Institute of Technology, 20(2), 72-88.

Dikici M \& Alhan C M (2018). Alibeyköy havzası için farklı hidrolojik modelleme yöntemleri ile taşkın debilerinin belirlenmesi. DÜMF Mühendislik Dergisi, 9(2), 919-928.

DSi (2012). Taşkınlar hidrolojisi tasarım rehberi, Orman ve Su İșleri Bakanlığı Devlet Su İşleri Genel Müdürlüğü yayınları, 56s.

DSi (Devlet Su İşleri Genel Müdürlüğü) (2017). Taşkın Yönetimi. Orman ve Su İşleri Bakanlığı Devlet Su İşleri Genel Müdürlüğü yayınları, 228s.

Elçi Ş, Tayfur G, Haltas İ \& Kocaman B (2017). Baraj yıkılması sonrası iki boyutlu taşkın yayılımının yerleşim bölgeleri için modellenmesi. Teknik Dergi, 28(3), 7955-7976.

Gamgam H (1998). Parametrik olmayan istatistiksel teknikler. Gazi Üniversitesi Yayını, 289s.

Hakan M (2008). Kızılırmak Havzasında taşkın frekans analizi. Yüksek Lisans Tezi. Kırıkkale Üniversitesi Fen Bilimleri Enstitüsü.

Haktanir T, Citakoglu H \& Seckin N (2016). Regional frequency analyses of successive-duration annual maximum rainfalls by L-moments method. Hydrological Sciences Journal, 61(4), 647-668.

Hsu S M, Chiou L B, Lin G F, Chao C H, Wen H Y \& Ku C Y (2010). Applications of simulation technique on debris-flow hazard zone delineation: A case study in Hualien County, Taiwan. Natural Hazards and Earth System Science, 10(3), 535-545.

İşler S, Oğuz E \& Durmuş O (2016). Antalya kemer ilçesi için sentetik yöntemlerle taşkın analizi. 4. Ulusal Taşkın Sempozyumu, 21-24 Kasım 2016, Rize, Türkiye.

Kaleyci H (2004). Değirmendere Havzası'nda taşkın frekans analizi ve taşkın sahalarının belirlenmesi. Yüksek Lisans Tezi, Karadeniz Teknik Üniversitesi Fen Bilimleri Enstitüsü.

Karapınar (2017). Bingöl Solhan Arakonak beldesi proje hesap raporu. DSi 94. Şube Müdürlüğü - Bingöl. 52s.

Kartal M (1998). Hipotez testleri. Şafak Yayınevi, Erzurum. 247s.

Keskin T E, Çetiner H İ, Başdağ S, Genç S \& Kılıç H Y (2018). Akım gözlem istasyonları bulunmayan nehirlerin DSİ Sentetik yöntemi kullanılarak taşkın debilerinin tahmini : Eskipazar Çayı Örneği (Karabük , Türkiye) 2. International Symposium on Natural Hazards and Disaster Management, 04-06 May 2019, Sakarya, Türkiye.

Keskiner A D \& Cetin M (2016). Taşkın hesaplarında kullanılan sentetik yöntemlerin küçük ölçekli sulama göletleri alt havzalarına uyarlanması: yaylalık göleti örneği. 4. Ulusal Taşkın Sempozyumu, 23 - 25 Kasım 
2016, Rize, Türkiye.

Kolmogorov A N (1933). Sulla determinazione empirica di una legge di distribuzione. Giornale Dell'Istituto Italiano Degli Attuari, 4, 83-91.

Kumanlıoğlu A A \& Ersoy S B (2018). Akım gözlemi olmayan havzalarda taşkın akımlarının belirlenmesi : Kızıldere Havzası. Dokuz Eylül ÜniversitesiMühendislik Fakültesi Fen ve Mühendislik Dergisi, 20(60), 890-904.

Maidment D (1992). Handbook of hydrology. New York: McGraw-Hill. 1424s.

Onuşluel Gül G \& Gül A (2010). İzmir Bostanlı Havzası için taşkın alanlarının HEC-HMS ve HEC-RAS modelleri ile belirlenmesi. 22-24 Mart 2010, Afyonkarahisar, Türkiye.

Özdemir H (1978). Uygulamalı taşkın hidrolojisi. DSİ Matbaasl. 221s.

Öztürk M, Kaya N \& Așkan A H (2003). Menfezlerin projelendirmesinde kullanılan taşkın hesap metotlarının değerlendirilmesi. Süleyman Demirel Üniversitesi Fen Bilimleri Enstitüsü Dergisi, 7(2), 167-171.

Şahin M A (2013). Ceyhan Havzası için bölgesel taşkın frekans analizi. Yüksek Lisans Tezi. Orta Doğu Teknik Üniversitesi Fen Bilimleri Enstitüsü.

Șahin Ö (2007). Van ili Gevaș-Gürpınar Havzasında çeșitli dağılımların karșılaștırılması ile tașkın frekans analizi. Yüksek Lisans Tezi. Niğde Üniversitesi Fen Bilimleri Enstitüsü.

Seçkin N (2002). Ceyhan ve Seyhan Havzalarının bölgesel taşkın frekans analizi. Yüksek Lisans Tezi. Çukurova Üniversitesi Fen Bilimleri Enstitüsü.

Seçkin N (2009). L-Momentlere dayalı gösterge-sel metodu ile bölgesel taşkın frekans analizi. Doktora Tezi. Cukurova Üniversitesi Fen Bilimleri Enstitüsü.

Şeker M (2015). Antalya Havzası'nın taşkın frekans analizi. Yüksek Lisans Tezi. Pamukkale Üniversitesi Fen Bilimleri Enstitüsü.

Şen Z (2009). Taşkın afet ve modern hesaplama yöntemleri. Su Vakfı Yayınları. 252s.

Singh K P (1980). Regional and sample skew values in flood-frequency analyses of streams in Illınois. Illinois State Water Survey. 159s.

Smirnov N V (1939). Estimate of deviation between empirical distribution functions in two independent samples. Bull Moscow University, 2, 3-16.

Sönmez 0, Hırca T \& Demir F (2017). Akım ölçümü olmayan nehirlerde farklı yağış akış modelleri ile tekerrürlü taşkın debisi hesabı: Mudurnu Çayı örneği. 5th International Symposium on Innovative Technologies in Engineering and Science. 29-30 September 2017. Bakü, Azerbaijan.

Sönmez 0, Öztürk M \& Doğan E (2012). İstanbul derelerinin taşkın debilerinin tahmini. Sakarya University Journal of Science, 16(2), 4-9.

Şorman Ü (2004). Bölgesel frekans analizindeki son gelişmeler ve bat, İMO Teknik Dergi, 212, 31553169.

Tayfur G (2017). Baraj yıkılma sonucu meydana gelen taşkın dalgası simülasyonu gerçekleştirme aşamaları, Su Vakfi, Su Külliyesi, 5, 1-15.

Ulke A, Beden N, Demir V \& Menek N (2017). Numerical modeling of Samsun Mert River floods. EWRA Publications, 57, 27-34.

Ülke A, Uslu A \& Beden N (2013). Samsun șehir tașkınlarının kronolojisi, 2012 yılı Samsun tașkını. 24-26 Ekim 2013, Mersin, Türkiye.

Ying X, Jorgeson J \& Wang S S Y (2009). Modeling dambreak flows using finite volume method on unstructured grid. engineering applications of computational fluid mechanics, 3(2), 184-194.

Yıldırım N (2013). Normal dağılım için uyum iyiliği testleri ve bir simülasyon çalıșması. Yüksek Lisans Tezi. Gazi Üniversitesi Fen Bilimleri Enstitüsü.

Yılmaz M (2016). Tașkın Riski ön değerlendirmesinde uzaktan algilama sistemlerinin kullanılabilirliği: Meriç nehrinde uygulanması. Uzmanlık Tezi Orman ve Su İşleri Bakanlığı. 